\title{
O SUPREMO TRIBUNAL FEDERAL NA CRISE POLÍTICA BRASILEIRA DE 2013-2018: SUAS FORÇAS E FRAQUEZAS DIANTE DAS ELITES POLÍTICAS
}

\author{
THE BRAZILIAN SUPREME COURT ON THE POLITICAL CRISIS 2013-2018: \\ ITS STRENGTHS AND WEAKNESSES BEFORE THE POLITICAL ELITE
}

\section{EL SUPREMO TRIBUNAL FEDERAL BRASILEÑO EN LA CRISIS POLÍTICA 2013- 2018: SUS FUERZAS Y FRAQUEZAS ANTE LAS ELITES POLÍTICAS}

\author{
FABRÍCIO CASTAGNA LUNARDI \\ https://orcid.org/0000-0002-9512-8394 / http://lattes.cnpq.br/2193609992569880 / fabricioclunardi@yahoo.com.br \\ Universidade de Brasília - UNB \\ Brasília, DF, Brasil
}

\begin{abstract}
RESUMO
0 presente artigo tem como objetivo investigar algumas decisões do Supremo Tribunal Federal que afrontam potencialmente interesses governistas e de elites políticas, as estratégias de que se utiliza para decidir e impor as suas decisões, bem como o agir da classe política para descumprir, direta ou indiretamente, se sobrepor ou retaliar a Corte Constitucional brasileira. Para tanto, a pesquisa se desenvolve com base na opção de uma linha críticometodológica, a partir da tópica e da metodologia jurídico-diagnóstica, buscando problematizar o tema a partir da análise qualitativa de casos selecionados, julgados pelo STF durante a crise política de 2013-2018, a fim de investigar as fragilidades da Corte e o conjunto de estratégias dos diversos atores nesse intrincado jogo político. Ao final, conclui-se que admitir as fragilidades do Supremo Tribunal Federal, considerar o intrincado jogo político em que está imersa e analisar o conjunto de estratégias dos diversos atores são premissas fundamentais para desenvolver estudos que possam contribuir para melhorar a capacidade institucional da Corte de decidir e impor as suas decisões quando elas afrontam interesses de elites políticas.
\end{abstract}

Palavras-chave: Crise política. Descumprimento. Elites políticas. Estratégias judiciais. Supremo Tribunal Federal.

\begin{abstract}
This paper has a purpose to investigate some decisions of the Federal Supreme Court that potentially confront interests of government and political elites, the strategies used to decide and impose its decisions, as well as the strategies of the political class to default, direct or indirectly, overlap or retaliate with the Brazilian Constitutional Court. To this end, the research is developed on the option of a critical-methodological line, based on the topic and the legal-diagnostic methodology, seeking to problematize the theme from the qualitative analysis of selected cases, judged by the STF during the political crisis 2013-2018, in order to investigate the weaknesses of the Court and the set of strategies of the various actors in this intricate political game. In the end, it is concluded that admitting the weaknesses of the Brazilian Constitutional Court, considering the intricate political game in which it is immersed and analyzing the set of strategies of the various actors are fundamental premises to develop studies that can contribute to improve the institutional capacity of the Court of decide and impose their decisions when they address the interests of political elites.
\end{abstract}

Keywords: Political crisis. Noncompliance. Political elites. Judicial strategies. Brazilian Constitutional Court.

\section{RESUMEN}

Este artículo tiene como objetivo investigar algunas decisiones del Supremo Tribunal Federal brasileño que potencialmente enfrentan intereses de las élites políticas y gubernamentales, las estrategias de que se utiliza para decidir e imponer sus decisiones, así como las estrategias de la clase política para incumplir, directa o indirectamente, sobreponerse o retar a la Corte Constitucional brasileña. Para este fin, la investigación se desarrolla en base a la opción de una línea crítico-metodológica, basada en el la tópica y la metodología de diagnóstico legal, 
O SUPREMO TRIBUNAL FEDERAL NA CRISE POLÍTICA BRASILEIRA DE 2013-2018: SUAS FORÇAS E FRAQUEZAS DIANTE DAS ELITES POLÍTICAS

buscando problematizar el tema a partir del análisis cualitativo de casos seleccionados, juzgados por el STF durante la crisis política 2013-2018, con el fin de investigar las debilidades de la Corte y el conjunto de estrategias de los diversos actores en este intrincado juego político. Al final, se concluye que admitir las fragilidades de la Corte Constitucional brasileña, considerar el intrincado juego político en que está inmersa y analizar el conjunto de estrategias de los diversos actores son premisas fundamentales para desarrollar estudios que puedan contribuir a mejorar la capacidad institucional de la Corte de decidir e imponer sus decisiones cuando afrontan los intereses de las élites políticas.

Palabras clave: Crisis política. Incumplimiento. Elites políticas. Estrategias judiciales. Supremo Tribunal Federal brasileño.

\section{SUMÁRIO}

INTRODUÇÃO; 1 HÁ EFETIVAMENTE UMA "SUPREMOCRACIA" NO BRASIL?; 2 A ATUAÇÃO DO STF NA CRISE POLÍTICA: A AUTORIDADE JUDICIAL EM XEQUE; 3 AS COMPLEXAS ESTRATÉGIAS JUDICIAIS PARA A EFETIVAÇÃO DAS DECISÕES E AS ESTRATÉGIAS POLÍTICAS DE DESCUMPRIMENTO: REFLEXÕES À LUZ DE ESTUDOS COMPARADOS; CONCLUSÃO; REFERÊNCIAS.

\section{INTRODUÇÃO}

A atuação do Supremo Tribunal Federal na política e nas questões estruturais têm ganhado centralidade nas pesquisas em direito constitucional nos últimos anos, especialmente diante do avanço da Corte Constitucional brasileira em searas que outrora eram deixadas aos demais Poderes Constituídos. As problematizações geralmente giram em torno da judicialização excessiva, do ativismo do STF, da legitimidade judicial e da politização da Corte Constitucional brasileira.

Ao abordar as problemáticas da atuação dos tribunais constitucionais e da expansão da jurisdição constitucional, grande parte dos estudos de constitucionais brasileiros ${ }^{1}$ põem ênfase na chamada "dificuldade contramajoritária". Todavia, no Brasil, os problemas judiciais e democráticos são muito maiores e mais complexos do que o da "dificuldade contramajoritária",

\footnotetext{
${ }^{1}$ Nesse sentido: BARROSO, Luís Roberto. Countermajoritarian, Representative, and Enlightened: The roles of constitutional tribunals in contemporary democracies. Revista Direito e Práxis, Rio de Janeiro, v. 9, n. 4, p. 2171-2228, Out-Dez. 2018. Disponível em: https://www.scielo.br/pdf/rdp/v9n4/2179-8966-rdp-9-42171.pdf. Acesso em: 14 jul. 2020; KÖHLER, Marco Vicente Dotto. Legitimidade democrática da jurisdição constitucional, dificuldade contramajoritária do Poder Judiciário e conflito intergeracional. Revista do CEJUR/TJSC: Prestação Jurisdicional, Florianópolis, v. 5, n. 01, p. 215-227, dez. 2017. Disponível em: https://revistadocejur.tjsc.jus.br/cejur/article/view/226/133. Acesso em: 14 jul. 2020. SOUZA NETO, Cláudio Pereira de; SARMENTO, Daniel. Notas sobre jurisdição constitucional e democracia: a questão da "última palavra" e alguns parâmetros de autocontenção judicial. Revista Quaestio luris, Rio de Janeiro, v. 6, n. 2, p. 119-161, 2013. Disponível em: https://www.epublicacoes.uerj.br/index.php/quaestioiuris/article/view/11773/9225. Acesso em: 14 jul. 2020.

2 Trata-se de expressão cunhada e desenvolvida por Alexander Bickel (The Least Dangerous Branch. New Haven: Yale University Press, 1986), que norteia grande parte das críticas direcionadas por constitucionalistas à revisão judicial de disposições normativas aprovadas por maiorias parlamentares.
} 
O SUPREMO TRIBUNAL FEDERAL NA CRISE POLÍTICA BRASILEIRA DE 2013-2018: SUAS FORÇAS E FRAQUEZAS DIANTE DAS ELITES POLÍTICAS

FABRÍCIO CASTAGNA LUNARDI

como adiante se mostrará. Aliás, há diversos incentivos para que as decisões de tribunais constitucionais sejam convergentes com a opinião da maioria ${ }^{3}$, como o acúmulo de capital político e a redução de ataques pelos demais Poderes Constituídos. ${ }^{4}$ Decisões contramajoritárias podem desgastar a imagem da Corte e diminuir o seu capital político, bem como dificultar o cumprimento da decisão judicial. Portanto, no Brasil, assim como em outros países da América Latina, a dificuldade contramajoritária está longe de ser o principal problema democrático vivenciado pela atuação dos tribunais constitucionais. Como afirma William Partlett, teóricos constitucionais, estudiosos e juízes talvez estejam fazendo as perguntas erradas quando buscam entender se a revisão judicial é democrática em abstrato. A experiência de direito constitucional comparado mostra que investigar os contextos é fundamental para determinar se tribunais desempenham ou não um papel de melhoramento da democracia. ${ }^{5}$

Além disso, a atuação do STF na crise política de 2013-2018 talvez mostre uma Corte Constitucional bem mais dependente e suscetível à classe política do que as teorias constitucionais standard são capazes explicar. Nesse tocante, é imprescindível a análise qualitativa de casos que envolvam interesses governistas e de elites políticas, a qual pode apresentar uma outra face do problema.

Desse modo, o presente trabalho pretende ir além da dicotomia ativismo judicial versus autocontenção, pois busca mostrar que os problemas judiciais e democráticos vivenciados no Brasil são bem mais complexos. Com base numa perspectiva dinâmica e contextualizada, busca-

\footnotetext{
${ }^{3}$ MELLO, Patrícia Perrone Campos. Quando julgar se torna um espetáculo: a interação entre o Supremo Tribunal Federal e a opinião pública, a partir de reflexões da literatura estrangeira. Revista de Direito Internacional, Brasília, v. 14, n. 1, p. 402-423, $2017 . \quad$ p. 420. Disponível em: https:// www.publicacoesacademicas.uniceub.br/rdi/article/view/4427/pdf. Acesso em: 14 jul. 2020.

4 "Figure 3 shows the distribution of attacks against Latin American high courts by country, combined with the previous data on public support. Roughly consistent with Friedman's thesis, note that countries with the highest frequency of crises are also those that tend to suffer from the lowest public approval ratings: Ecuador, Argentina, Bolivia, and Paraguay. Likewise, judiciaries with the highest public approval ratings have had the fewest attacks (Costa Rica, Colombia, Brazil, El Salvador, Panama, Uruguay, and Dominican Republic). Chile and Venezuela are the only two countries that do not fit the apparent pattern. In the case of Chile, however, it is worth noting that most of the threats did not come to fruition. The fact that the incidence of attacks throughout the region has tended to increase in the last two decades, while public support has generally decreased, is also roughly in line with the central thesis. Of course, from these descriptive data we cannot tell the direction of the causal arrow-it may be that attacks are lowering public support for the courts, not vice versa. Nor can we control for the influence of other plausible explanations for juridical instability" (HELMKE, Gretchen. Public Support and Judicial Crises in Latin America. Journal of Constitutional Law, v. 13, n. 2, p. 397-411, 2010. pp. 402/403. Disponível em: https://scholarship.law.upenn.edu/cgi/viewcontent.cgi?article=1079\&context=jcl. Acesso em: 14 jul. 2020).

${ }^{5}$ PARTLETT, William. Courts and Constitution-Making. Wake Forest Law Review, Wake Forest University School of Law, Winston-Salem, CN, v. 50, p. 921-949, 2015. p. 948. Disponível em: https: / / papers.ssrn.com/sol3/papers.cfm?abstract_id=2730359. Acesso em: 14 jul. 2020.
} 
se colocar em questão as teses de "ditadura" do STF ${ }^{6}$ e de "supremocracia"7, por serem subcomplexas para explicar o fenômeno. Além disso, pretende-se investigar como tem sido a atuação do Supremo quando confronta interesses do governo federal ou de elites políticas, quais são as estratégias que utiliza para buscar o cumprimento das suas decisões e como as elites políticas buscam descumprir, se evadir ou retaliar a Corte Constitucional brasileira.

Para atingir os seus escopos, a pesquisa se desenvolve com base na opção de uma linha crítico-metodológica, a partir da tópica e da metodologia jurídico-diagnóstica, buscando problematizar o tema a partir da análise qualitativa de casos selecionados, a seguir descritos, julgados pelo STF durante a crise política que se iniciou em 2013 e durou até a eleição presidencial de 2018, a fim de investigar as fragilidades da Corte e o conjunto de estratégias dos diversos atores nesse intrincado jogo político. Com base nessa metodologia, pretende-se investigar qual é o grau de independência e suscetibilidade da Corte Constitucional brasileira em relação a elites políticas e ao governo federal. Além disso, a partir de estudos da ciência política e de direito constitucional, buscar-se-á compreender melhor as estratégias utilizadas pelo STF para fazer valer as suas decisões, bem como as estratégias da classe política para descumprir, direta ou indiretamente, reverter ou retaliar a Corte Constitucional brasileira.

Assim, o presente artigo foi dividido em três partes. Inicialmente, pretende-se colocar em questão as teses que preconizam a existência de uma "ditatura" do STF $^{8}$ ou uma "supremocracia", mostrando que elas ignoram as situações em que a autoridade da Corte brasileira é colocada em xeque por atores políticos relevantes. Após, pretende-se mostrar a atuação do STF durante a crise política brasileira que se iniciou em 2013, diante do julgamento das seguintes causas, que envolvem direitos estruturais e interesses governistas ou de elites políticas: Mandado de Segurança $n .^{\circ} 34070^{10}$, que questionava a nomeação de Luiz Inácio Lula da

6 DELMANTO, Roberto. A ditadura do Judiciário. Migalhas, 15 mar. 2018. Disponível em: http://www.migalhas.com.br/dePeso/16,MI276327,101048-A+ditadura+do+Judiciario. Acesso em: 10 mar. 2019.

7 VILHENA, Oscar. Supremocracia. Revista de Direito do Estado, Rio de Janeiro, a. 3, n. 12, p. 55-75, out.-dez. 2008. Disponível em: https://www.scielo.br/pdf/rdgv/v4n2/a05v4n2.pdf. Acesso em: 14 jul. 2020.

8 DELMANTO, Roberto. A ditadura do Judiciário. Migalhas, 15 mar. 2018. Disponível em: http://www.migalhas.com.br/dePeso/16,MI276327,101048-A+ditadura+do+Judiciario. Acesso em: 10 mar. 2019.

9 VILHENA, Oscar. Supremocracia. Revista de Direito do Estado, Rio de Janeiro, a. 3, n. 12, p. 55-75, out.-dez. 2008. Disponível em: https://www.scielo.br/pdf/rdgv/v4n2/a05v4n2.pdf. Acesso em: 14 jul. 2020.

10 BRASIL. Supremo Tribunal Federal. Mandado de Segurança n. ${ }^{\circ}$ 34070. Suspende a nomeação de Luiz Inácio Lula da Silva para o cargo de Ministro da Casa Civil, pela então Presidenta Dilma Rousseff. Impetrante: Partido Popular Socialista. Impetrado: Presidente da República. Medida Cautelar. Liminar. Relator: Min. Gilmar Mendes. Julgado em 18 mar. 2016. Diário da Justiça Eletrônico: Brasília, DF, n. 54, 
O SUPREMO TRIBUNAL FEDERAL NA CRISE POLÍTICA BRASILEIRA DE 2013-2018: SUAS FORÇAS E FRAQUEZAS DIANTE DAS ELITES POLÍTICAS

FABRÍCIO CASTAGNA LUNARDI

Silva para o cargo de Ministro da Casa Civil, pela então Presidenta Dilma Rousseff; Ação Cautelar n. ${ }^{\circ} 4070^{11}$, em que se postulava a suspensão do mandato do então Deputado Federal Eduardo Cunha, para afastá-lo da presidência da Câmara dos Deputados e do exercício do mandato parlamentar; Ação de Descumprimento de Preceito Fundamental n. ${ }^{\circ} 402^{12}$, em que se discutiu o afastamento de Renan Calheiros da Presidência do Senado; Ação Cautelar n. ${ }^{\circ} 4327^{13}$, em que se postulava a prisão preventiva ou a fixação de medidas cautelares diversas da prisão ao Senador Aécio Neves, e também se questionava se essas medidas deveriam ser deliberadas pela sua Casa Legislativa; Ação Direta de Inconstitucionalidade $n .^{\circ} 5526^{14}$, que discutia abstratamente a mesma questão, ou seja, se a Casa Legislativa poderia deliberar sobre as medidas cautelares fixadas pelo Judiciário ao congressista, quando causassem embaraço à sua atividade parlamentar; Ação Direta de Inconstitucionalidade $n .{ }^{\circ} 4650^{15}$, em que se postulava a proibição

28 mar. 2016. Disponível em: http://www.stf.jus.br/arquivo/cms/noticiaNoticiaStf/anexo/ms34070.pdf. Acesso em: 14 jul. 2020.

11 BRASIL. Supremo Tribunal Federal. Ação Cautelar n. ${ }^{\circ}$ 4070. Suspende o mandato do então Deputado Federal Eduardo Cunha, para afastá-lo da presidência da Câmara dos Deputados e do exercício do mandato parlamentar. Autor: Procurador-Geral da República. Réu: Eduardo Cosentino da Cunha. Relator: Ministro Teori Zavascki. Tribunal Pleno. Julgado em 5 mai. 2016. Acórdão eletrônico. Diário da Justiça Eletrônico: Brasília, DF, n. 225, 21 out. 2016. Disponível em: http:// www.stf.jus.br/portal/cms/verNoticiaDetalhe.asp?idConteudo=316009. Acesso em: 14 jul. 2020.

12 BRASIL. Supremo Tribunal Federal. Ação de Descumprimento Fundamental n. ${ }^{\circ} 402$. Pretende o afastamento cautelar do exercício da Presidência do Senado Federal, por ser réu em processo penal. Autor: Rede Sustentabilidade. Réu: Presidente da Câmara dos Deputados. Relator: Ministro Marco Aurélio. Acompanhamento processual. Disponível em: http://www.stf.jus.br/portal/processo/verProcessoAndamento.asp?incidente $=4975492$. Acesso em: 10 mar. 2019.

13 BRASIL. Supremo Tribunal Federal. Ação Cautelar n. ${ }^{\circ}$ 4327. Agravo regimental. Postula a prisão preventiva ou a fixação de medidas cautelares diversas da prisão ao Senador Aécio Neves, e também se questionava se essas medidas deveriam ser deliberadas pela sua Casa Legislativa. Autor: Ministério Público Federal. Réu: Aécio Neves Da Cunha. Relator: Ministro Marco Aurélio, Relator p/ Acórdão: Ministro Roberto Barroso. Primeira Turma. Julgado em 26 set. 2017. Diário da Justiça Eletrônico: Brasília, DF, n. 247, 272017.2 Disponível 2 http:// www.stf.jus.br/portal/cms/verNoticiaDetalhe.asp?idConteudo=356966. Acesso em: 14 jul. 2020.

${ }^{14}$ BRASIL. Supremo Tribunal Federal. Ação Direta de Inconstitucionalidade n. ${ }^{\circ}$ 5526. Julgado parcialmente procedente o pedido. 0 Poder Judiciário dispõe de competência para impor, por autoridade própria, as medidas cautelares a que se refere o art. 319 do Código de Processo Penal, mas deve se encaminhar à Casa Legislativa a que pertencer o parlamentar, para os fins a que se refere o art. 53 , $\S 2^{\circ}$, da Constituição, a decisão pela qual se aplique medida cautelar, sempre que a execução desta impossibilitar, direta ou indiretamente, o exercício regular de mandato parlamentar. Requerentes: Partido Progressista PP; Partido Social Cristão - PSC. Relator p/ acórdão: Ministro Alexandre de Moraes. Julgado em 11 out. 2017. Diário da Justiça Eletrônico: Brasília, DF, n. 159, 7 ago. 2018. Disponível em: http:// www.stf.jus.br/portal/cms/verNoticiaDetalhe.asp?idConteudo=362170. Acesso em: 14 jul. 2020.

${ }^{15}$ BRASIL. Supremo Tribunal Federal. Ação Direta de Inconstitucionalidade n. ${ }^{\circ}$ 4650. Julgado parcialmente procedente $\mathrm{o}$ pedido. Declarou a inconstitucionalidade dos dispositivos legais que autorizavam as contribuições de pessoas jurídicas às campanhas eleitorais. Com relação às pessoas físicas, as contribuições ficam reguladas pela lei em vigor. Autor: Conselho Federal da Ordem dos Advogados do Brasil. Requeridos: Congresso Nacional; Presidente da República. Relator: Ministro Luiz Fux. Tribunal 
de doações de pessoas jurídicas a candidatos. A análise do julgamento de tais questões, dentro dos respectivos contextos, auxiliará a evidenciar a força e as fraquezas da Corte Constitucional brasileira. A seguir, com base em estudos de cientistas políticos e de pesquisadores de direito constitucional comparado, buscar-se-á mostrar reflexivamente quais as estratégias que são comumente utilizadas pelas Cortes Constitucionais para implementarem as suas decisões, e como as elites políticas buscam descumprir, direta ou indiretamente, retaliar ou reverter as decisões judiciais.

Por “elites políticas”, expressão amplamente utilizada neste artigo, pretende-se designar o conjunto de indivíduos que detêm mais poder em determinado grupo, que são capazes de participar diretamente do processo de tomada de decisão, incluindo a não-decisão (segundo a perspectiva neoelitista), de modo que as suas escolhas podem ser impostas à população, ou seja, afetam um grande número de pessoas, ainda que não se deva recair num voluntarismo, já que não se pode desprezar os constrangimentos estruturais que limitam a liberdade de ação essas elites. ${ }^{16}$ Assim, também se inclui nesse conceito a classe eleita, mas não somente ela, pois há políticos não eleitos que possuem participação direta nessas escolhas que afetam a população. Além disso, com base pluralista, também se inclui nessa designação os indivíduos que compõem organizações não-estatais, sobretudo "grandes corporações econômicas, cujas decisões têm efeitos sociais e políticos inegáveis" ${ }^{17}$. A perspectiva adotada também não ignora o seu caráter dinâmico, ou seja, a existência de "circulação das elites", diante da "passagem de um a outro grupo". ${ }^{18}$

Assim, o presente artigo pretende ser um convite à reflexão sobre a atuação da Corte Constitucional brasileira na crise política que se iniciou em 2013, permitindo que possa chegar às suas próprias conclusões.

Pleno. Julgado em 17 set. 2015. Diário da Justiça Eletrônico: Brasília, DF, n. 34, 24 fev. 2016. Disponível em: http://www.stf.jus.br/portal/cms/verNoticiaDetalhe.asp?idConteudo=300015. Acesso em: 14 jul. 2020.

16 PERISSINOTTO, Renato. As elites políticas: questões de teoria e método. Curitiba: IBPEX, 2009. pp. 83/84/97.

17 PERISSINOTTO, Renato. As elites políticas: questões de teoria e método. Curitiba: IBPEX, 2009. pp. $81 / 82$.

18 PERISSINOTTO, Renato. As elites políticas: questões de teoria e método. Curitiba: IBPEX, 2009. p. 34. 


\section{HÁ EFETIVAMENTE UMA “SUPREMOCRACIA” NO BRASIL?}

Em razão de teses sobejamente ativistas e expansionistas da função judicial, alguns autores, como Roberto Delmanto, falam numa "ditadura" do Poder Judiciário ${ }^{19}$. Oscar Vilhena critica essa expansão da autoridade do Supremo Tribunal Federal em relação aos demais Poderes da República, chamando esse fenômeno de "supremocracia"20. Para o autor, a Corte Constitucional brasileira estaria exercendo uma espécie de poder moderador, uma vez que teria a prerrogativa de dar a última palavra sobre inúmeras questões de natureza substantiva, por vezes substituindo escolhas majoritárias. Segundo Vilhena, o problema não estaria nas atribuições conferidas ao STF, mas na escala e na natureza das suas intervenções em temas cujas soluções não seriam ou não deveriam ser de natureza puramente jurídica ou constitucional. ${ }^{21}$

De outro lado, os autores que apoiam o avanço do controle judicial de constitucionalidade em detrimento das opções políticas legislativas comumente fundamentam as suas teses em casos em que o Judiciário tomou decisões que protegeram os direitos fundamentais, ou que foram vistas como justas e corretas. ${ }^{22}$ Os casos repetidos são quase sempre os mesmos: a) declaração de constitucionalidade da Lei de Biossegurança, que permitiu a realização de pesquisas com células-tronco embrionárias (STF, ADI n. ${ }^{\circ} 3510,2010^{23}$ ); b) declaração de constitucionalidade da política de cotas raciais em universidades públicas (STF, ADPF n. $\left.{ }^{\circ} 186,2012^{24}\right)$; c) descriminalização do aborto de feto anencefálico (STF, ADPF n. ${ }^{\circ} 54$,

19 DELMANTO, Roberto. A ditadura do Judiciário. Migalhas, 15 mar. 2018. Disponível em: http://www.migalhas.com.br/dePeso/16,MI276327,101048-A+ditadura+do+Judiciario . Acesso em: 10 mar. 2019.

20 VILHENA, Oscar. Supremocracia. Revista de Direito do Estado, Rio de Janeiro, a. 3, n. 12, p. 55-75, out.-dez. 2008. p. 59. Disponível em: https://www.scielo.br/pdf/rdgv/v4n2/a05v4n2.pdf. Acesso em: 24 jul. 2020.

21 VILHENA, Oscar. Supremocracia. Revista de Direito do Estado, Rio de Janeiro, a. 3, n. 12, p. 55-75, out.-dez. 2008. p. 60. Disponível em: https://www.scielo.br/pdf/rdgv/v4n2/a05v4n2.pdf. Acesso em: 24 jul. 2020.

22 BARROSO, Luís Roberto. Curso de direito constitucional contemporâneo: os conceitos fundamentais e a construção do novo modelo. 3. ed. São Paulo: Saraiva, 2011.

${ }^{23}$ BRASIL. Supremo Tribunal Federal. Ação Direta de Inconstitucionalidade n. ${ }^{\circ} 3510$. Pede a declaração de inconstitucionalidade de dispositivos a Lei de Biossegurança (Lei n. ${ }^{\circ}$ 11.105/2005). Julgados improcedentes os pedidos. Requerente: Procurador-Geral da República. Requeridos: Presidente da República; Congresso Nacional. Relator: Ministro Ayres Britto. Tribunal Pleno. Julgado em 29 mai. 2008. DJe-096, 28 mai. 2010. Revista Trimestral de Jurisprudência, Brasília, v. 214.Disponível em: http://www.stf.jus.br/arquivo/cms/publicacaoRTJ/anexo/214_1.pdf. Acesso em 14 jul. 2020.

${ }^{24}$ BRASIL. Supremo Tribunal Federal. Ação de Descumprimento Fundamental $n .^{\circ} 186$. Questiona atos que instituíram sistema de reserva de vagas com base em critério étnico-racial (cotas) no processo de seleção 
O SUPREMO TRIBUNAL FEDERAL NA CRISE POLÍTICA BRASILEIRA DE 2013-2018: SUAS FORÇAS E FRAQUEZAS DIANTE DAS ELITES POLÍTICAS

FABRÍCIO CASTAGNA LUNARDI

$2012^{25}$ ); d) reconhecimento de existência de união estável entre casais homoafetivos (STF, ADI n. ${ }^{\circ}$ 4277, 201126; STF, ADPF n. ${ }^{\circ}$ 132, 2011 ${ }^{27}$ ); e) declaração de inconstitucionalidade da cláusula de barreira que dificultaria a criação e reduziria o funcionamento parlamentar dos partidos menores (STF, ADI n. ${ }^{\circ} 1351,2007^{28}$ ).

Contudo, nos dois primeiros casos, há sérias dúvidas se houve realmente uma postura ativista ou, ao contrário, de autocontenção, pois o STF reconheceu a constitucionalidade das leis impugnadas ${ }^{29}$. No terceiro e no quarto casos, está-se diante de proteção de direitos individuais, algo que seria inerente à sua própria missão constitucional. No último caso, haveria a intromissão do STF na seara política, para "proteger minorias partidárias", mas diversos

para ingresso em instituição pública de ensino superior. Julgados improcedentes os pedidos. Requerente: DEMOCRATAS - DEM. Requerido: Conselho de Ensino, Pesquisa e Extensão da Universidade de Brasília CEPE; Reitor da Universidade de Brasília. Relator: Ministro Ricardo Lewandowski. Julgado em 26 abr. 2012. Diário da Justiça Eletrônico: Brasília, DF, n. 86, 4 mai. 2012. Disponível em: http: / / www.stf.jus.br/portal/cms/verNoticiaDetalhe.asp?idConteudo=278000. Acesso em 14 jul. 2020.

${ }^{25}$ BRASIL. Supremo Tribunal Federal. Ação de Descumprimento de Preceito Fundamental n. ${ }^{\circ} 54$. Julgada procedente a ação para declarar a inconstitucionalidade da interpretação segundo a qual a interrupção da gravidez de feto anencéfalo é conduta tipificada nos artigos 124, 126, 128, incisos I e II, todos do Código Penal. Requerente: Confederação Nacional dos Trabalhadores na Saúde - CNTS. Requerido: Presidente da República. Relator: Ministro Marco Aurélio. Tribunal Pleno. Julgado em 12 abr. 2012. Diário da Justiça Eletrônico: Brasília, DF, n. 77, 20 abr. 2012. Disponível em: http: //redir.stf.jus.br/paginadorpub/paginador.jsp?docTP=TP\&docID=3707334. Acesso em: 14 jul. 2020.

${ }^{26}$ BRASIL. Supremo Tribunal Federal. Ação Direta de Inconstitucionalidade n. ${ }^{\circ}$ 4277. Interpretação do art. 1.723 do Código Civil em conformidade com a Constituição Federal (técnica da "interpretação conforme"). Reconhecimento da união homoafetiva como família. Julgada procedente a ação. Requerente: Procuradora-Geral da República. Requerido: Presidente da República; Congresso Nacional. Relator: Ministro Ayres Britto. Tribunal Pleno. Julgado em 5 mai. 2011. Diário da Justiça Eletrônico: Brasília, DF, n. 198, 14 out. 2011. Disponível em: http://redir.stf.jus.br/paginadorpub/paginador.jsp?docTP=AC\&docID=628635. Acesso em 14 jul. 2020.

${ }^{27}$ BRASIL. Supremo Tribunal Federal. Ação de Descumprimento de Preceito Fundamental n. ${ }^{\circ} 132$. Perda parcial de objeto. Recebimento, na parte remanescente, como ação direta de inconstitucionalidade. Interpretação do art. 1.723 do Código Civil em conformidade com a Constituição Federal (técnica da “interpretação conforme”). Reconhecimento da união homoafetiva como família. Procedência das ações. Requerente: Governador do Estado do Rio De Janeiro. Requeridos: Tribunais de Justiça dos Estados. Relator: Ministro Ayres Britto. Tribunal Pleno. Julgado em 5 mai. 2011. Diário da Justiça Eletrônico: Brasília, DF, n. 198, 14 out. 2011. Disponível em: https: //redir.stf.jus.br/paginadorpub/paginador.jsp?docTP=AC\&docID=628633. Acesso em: 14 jul. 2020.

${ }^{28}$ BRASIL. Supremo Tribunal Federal. Ação Direta de Inconstitucionalidade n. ${ }^{\circ} 1351$. Julgada procedente a ação para declarar inconstitucionalidade de dispositivos de lei que, em face da gradação de votos obtidos por partido político, afasta o funcionamento parlamentar e reduz, substancialmente, o tempo de propaganda partidária gratuita e a participação no rateio do Fundo Partidário. Requerente: Partido Comunista do Brasil - PC do B e outros. Relator: Ministro Marco Aurélio. Tribunal Pleno. Julgado em 7 dez. 2006. Diário da Justiça de 30 mar. 2007. Revista Trimestral de Jurisprudência, Brasília, v. 207-01, p. 116. Disponível em: http://redir.stf.jus.br/paginadorpub/paginador.jsp?docTP=AC\&docID=416150. Acesso em: 14 jul. 2020.

29 ARGUELHES, Diego Werneck; LIMA, João Marcelo da Costa e Silva. Políticas públicas, interpretação judicial e as intenções do legislador: o ProUni e o "cripto-ativismo" do Supremo Tribunal Federal. Revista de Investigações Constitucionais, Curitiba, v. 4, n. 2, p. 163-192, mai.-ago. 2017. p. 164. Disponível em: https://www.scielo.br/pdf/rinc/v4n2/2359-5639-rinc-04-02-0163.pdf. Acesso em: 14 jul. 2020. 
O SUPREMO TRIBUNAL FEDERAL NA CRISE POLÍTICA BRASILEIRA DE 2013-2018: SUAS FORÇAS E FRAQUEZAS DIANTE DAS ELITES POLÍTICAS

FABRÍCIO CASTAGNA LUNARDI

ministros da Corte já reconheceram que essa decisão foi um erro, pelas consequências negativas que gerou. $^{30}$ Portanto, a análise qualitativa demanda uma investigação um pouco mais aprofundada e menos isolacionista.

Ademais, se considerados os dados estatísticos sobre ações diretas de inconstitucionalidade, do ano 2000 até 15/11/2018, observa-se que apenas 23,79\% (vinte e três inteiros e setenta e nove centésimos por cento) delas foram julgadas procedentes, e 7,18\% (sete inteiros e dezoito centésimos por cento) foram parcialmente procedentes ${ }^{31}$. De outro lado, considerando os dados estatísticos das ações declaratórias de constitucionalidade do ano 2000 até $15 / 11 / 2018$, observa-se que apenas $22,86 \%$ (vinte e dois inteiros e oitenta e seis centésimos por cento) delas foram julgadas improcedentes ${ }^{32}$. Isso sugere que, ao menos quantitativamente, o grau de intervenção do STF para derrubada da legislação em geral e de ativismo judicial não é tão alto assim, embora esses números possam dar ensejo a diversas interpretações.

Além disso, pragmaticamente, essas teses de “ditadura do Poder Judiciário"33 e "supremocracia" 34 servem para realçar um problema relacionado ao avanço do Judiciário em determinadas áreas, mas, em verdade, não condizem com a atuação da Corte Constitucional brasileira frente às elites políticas ou sobre questões estruturais ${ }^{35}$, e, se não contextualizadas, dizem pouco sobre a complexidade que cerca a questão.

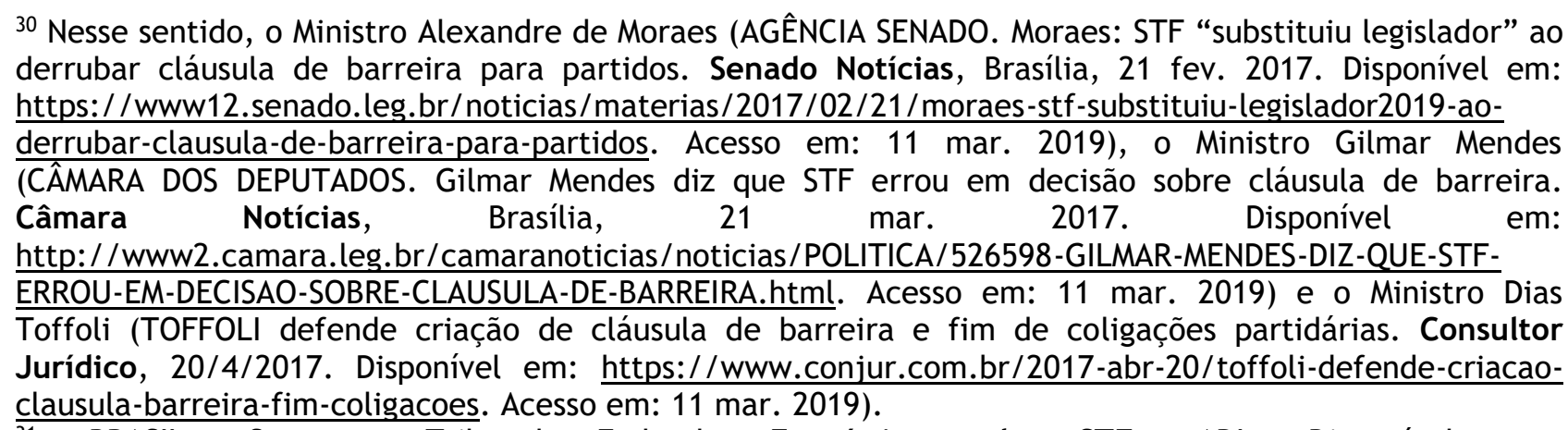
31 BRASIL. Supremo Tribunal Federal. Estatísticas do STF: ADI. Disponível em: http://www.stf.jus.br/portal/cms/verTexto.asp?servico=estatistica\&pagina=adi. Acesso em: 15 nov. 2018.

32 BRASIL. Supremo Tribunal Federal. Estatísticas do STF: ADC. Disponível em: http://www.stf.jus.br/portal/cms/verTexto.asp?servico=estatistica\&pagina=adc. Acesso em: 15 nov. 2018.

33 DELMANTO, Roberto. A ditadura do Judiciário. Migalhas, 15 mar. 2018. Disponível em: http://www.migalhas.com.br/dePeso/16,MI276327,101048-A+ditadura+do+Judiciario. Acesso em: 10 mar. 2019.

34 VILHENA, Oscar. Supremocracia. Revista de Direito do Estado, Rio de Janeiro, a. 3, n. 12, p. 55-75, out.-dez. 2008. p. 59. Disponível em: https://www.scielo.br/pdf/rdgv/v4n2/a05v4n2.pdf. Acesso em: 24 jul. 2020.

${ }_{35}$ As questões estruturais, por vezes chamadas de direitos estruturais, regras estruturais ou estrutura constitucional, dizem respeito à forma de estruturação das instituições, suas competências e poderes, formas de inter-relacionamento e controle. São questões estruturais, por exemplo, as referentes às 
Assim, é mais produtivo analisar a questão de forma dinâmica, de modo que sejam considerados o contexto político em que os tribunais constitucionais se inserem; as estratégias das elites políticas para descumprirem, direta ou indiretamente, as decisões judiciais; as estratégias políticas de que se utiliza a corte constitucional para aumentar as probabilidades de sucesso no exercício da revisão judicial e no cumprimento de suas decisões. Enfim, é preciso investigar como, na seara do direito constitucional comparado e no âmbito doméstico, ela acumula capital político para tomar decisões contrárias às elites políticas, bem como estas, na prática, buscarão descumprir, reverter ou se evadir das decisões judiciais.

A análise qualitativa da atuação do STF durante a crise política vivenciada pelo Brasil a partir de 2013 pode revelar uma Corte Constitucional bem mais frágil, que decide considerando os seus próprios limites, o que se pretende desenvolver a seguir.

\section{A ATUAÇÃO DO STF NA CRISE POLÍTICA: A AUTORIDADE JUDICIAL EM XEQUE}

A historiografia recente da atuação do STF em relação à crise político-institucional e às elites políticas têm muito a dizer sobre a independência, o poder jurídico e a autoridade da Corte quando está diante de interesses governistas ou de elites políticas. Analisar qualitativamente os casos acima referidos, julgados pela Corte Constitucional brasileira no contexto dessa crise, será importante para mostrar a centralidade do tema e problematizá-lo adequadamente.

A então Presidenta Dilma Rousseff, no auge da crise política do seu governo, nomeou para o cargo de Ministro da Casa Civil o ex-Presidente Luiz Inácio Lula da Silva (em 16/03/2016). Ocorre que havia sido autorizada judicialmente a interceptação telefônica de Lula e, no mesmo dia da nomeação, foi divulgada ao público uma conversa entre Lula e Dilma, em que esta dizia que estaria enviando àquele antecipadamente um termo de posse como um salvo-conduto para o

competências dos Poderes Constituídos, aos seus poderes, ao federalismo, ao sistema de governo, ao sistema de freios e contrapesos. Nesse sentido, Ozan Varol: "Constitutional theory establishes a dichotomy between constitutional structure and constitutional rights. Conventional wisdom suggests that certain constitutional provisions are structural in nature because they establish and empower the basic institutions of government. For example, provisions related to federalism, separation of powers, and checks and balances-which appear in the first three articles of the U.S. Constitution-are firmly considered structural. In contrast, other provisions, such as those that appear in the Bill of Rights, are considered rights provisions because they restrict government power and protect the individual from the government" (VAROL, Ozan O. Structural Rights. Georgetown Law Journal, v. 105, n. 4, p. 1001-1054, abr. 2017 Disponível em: https://papers.ssrn.com/sol3/papers.cfm?abstract_id=2746175. Acesso em: 14 jul. 2020). 
O SUPREMO TRIBUNAL FEDERAL NA CRISE POLÍTICA BRASILEIRA DE 2013-2018: SUAS FORÇAS E FRAQUEZAS DIANTE DAS ELITES POLÍTICAS

FABRÍCIO CASTAGNA LUNARDI

caso de ser expedido um mandado de prisão contra Lula pela Justiça Federal de primeira instância. Diante da divulgação dos áudios, foram realizados diversos protestos populares contra esse ato. ${ }^{36}$

Com isso, não tardou para que partidos políticos impugnassem tal ato no Supremo Tribunal Federal. Em 18/03/2016, o Ministro do STF Gilmar Mendes determinou a suspensão da nomeação de Lula para o cargo, fundamentando que existiu desvio de finalidade. Para o mesmo Ministro, a então Presidenta Dilma apenas teria nomeado Lula a fim de que eventual processo criminal contra ele tramitasse e fosse julgado pelo STF, onde há foro por prerrogativa de função dos Ministros de Estado (STF, MS n. ${ }^{\circ} 34070,2016^{37}$ ).

Essa decisão monocrática do Ministro Gilmar Mendes, que talvez não refletisse a opinião da maioria do Tribunal, foi determinante para mudar os rumos políticos do país num contexto em que a então Presidenta Dilma tinha perdido a sua base política aliada, havia crise econômica, escândalos de corrupção e protestos populares pedindo o seu impeachment. ${ }^{38}$

Outra decisão do STF impactaria no destino político do país. Em 05/05/2016, o Supremo, por seu órgão pleno, ao analisar a medida liminar na Ação Cautelar $n .^{\circ} 4.070^{39}$, decidiu, por unanimidade, suspender o mandato do então Deputado Federal Eduardo Cunha (MDB-RJ) e afastá-lo da presidência da Câmara dos Deputados e do exercício do mandato parlamentar. Na decisão, o principal fundamento era de que havia contra ele ações penais em andamento e ele estaria dificultando as investigações (STF, AC n. ${ }^{\circ} 4070,2016^{40}$ ).

${ }^{36}$ MORO divulga grampo de Lula e Dilma; Planalto fala em Constituição violada. G1, São Paulo, 16 mar. 2016. Disponível em: http://g1.globo.com/politica/noticia/2016/03/moro-divulga-grampo-de-lula-edilma-planalto-fala-em-constituicao-violada.html. Acesso em: 13 mar. 2019.

37 BRASIL. Supremo Tribunal Federal. Mandado de Segurança n. ${ }^{\circ}$ 34070. Suspende a nomeação de Luiz Inácio Lula da Silva para o cargo de Ministro da Casa Civil, pela então Presidenta Dilma Rousseff. Impetrante: Partido Popular Socialista. Impetrado: Presidente da República. Medida Cautelar. Liminar. Relator: Min. Gilmar Mendes. Julgado em 18 mar. 2016. Diário da Justiça Eletrônico: Brasília, DF, n. 54, 28 mar. 2016. Disponível em: https://www.stf.jus.br/arquivo/cms/noticiaNoticiaStf/anexo/ms34070.pdf. Acesso em: 14 jul. 2020.

${ }^{38}$ Essa decisão liminar do Ministro Gilmar Mendes, que foi determinante para os rumos políticos do país, jamais teve o seu mérito julgado. Com efeito, em 11/5/2016, um dia antes do afastamento temporário da Presidenta Dilma Rousseff, em razão da admissibilidade da denúncia pelo Senado (ocorrido em 12/5/2016), ela exonerou diversos Ministros, inclusive o ex-Presidente Lula. Com base nisso, em 16/5/2016, o Ministro Gilmar Mendes julgou prejudicado o mérito dos referidos mandados de segurança, de modo que o Pleno do STF nunca chegou a apreciar o referido pedido liminar.

${ }^{39}$ A Procuradoria-Geral da República havia ajuizado a Ação Cautelar n. ${ }^{\circ} 4.070$ em 16/12/2015 contra o Deputado Federal Eduardo Cunha, para afastá-lo do cargo.

40 BRASIL. Supremo Tribunal Federal. Ação Cautelar n. ${ }^{\circ}$ 4070. Suspende o mandato do então Deputado Federal Eduardo Cunha, para afastá-lo da presidência da Câmara dos Deputados e do exercício do mandato parlamentar. Autor: Procurador-Geral da República. Réu: Eduardo Cosentino da Cunha. Relator: Ministro Teori Zavascki. Tribunal Pleno. Julgado em 5 mai. 2016. Acórdão eletrônico. Diário da 
O SUPREMO TRIBUNAL FEDERAL NA CRISE POLÍTICA BRASILEIRA DE 2013-2018: SUAS FORÇAS E FRAQUEZAS DIANTE DAS ELITES POLÍTICAS

O Supremo tomou essa decisão, contra um poderoso político do país, mas o fez com grande apoio popular, da mídia e, inclusive, de outros parlamentares. Eduardo Cunha era alvo de denúncias e investigações por corrupção. Além disso, havia contra ele forte rejeição popular, pois, nos diversos protestos pelo país, os manifestantes pediam a sua saída do poder. No âmbito político, chegou-se a questionar a demora do STF ao decidir a medida liminar, já que o Deputado Federal Eduardo Cunha foi um ator político relevante no impeachment da ex-Presidenta Dilma Rousseff, e a decisão que o afastou somente foi proferida seis meses após a ação ter sido ajuizada, quando o processo de impeachment já havia sido admitido pela Câmara dos Deputados e encaminhado para o Senado Federal. ${ }^{41}$

Entretanto, a mesma força não socorreu a Corte Constitucional brasileira no julgamento da ADPF n. ${ }^{\circ} 402^{42}$ e no caso do Senador Renan Calheiros. Em 05/12/2016, o Ministro do STF Marco Aurélio Mello, de forma monocrática, determinou liminarmente o afastamento de Renan Calheiros da Presidência do Senado ${ }^{43}$. Em sua decisão, fundamentou que, como o Senador Renan Calheiros se tornou réu em ação de natureza penal, estaria impedido de ocupar qualquer cargo que o deixasse na linha sucessória da Presidência da República ${ }^{44}$. Ocorre que, no dia seguinte (06/12/2016), a Mesa Diretora do Senado decidiu que não cumpriria a decisão judicial, bem como que aguardaria um julgamento pelo Pleno do STF. ${ }^{45} \mathrm{Em}$ outras palavras, houve um

Justiça Eletrônico: Brasília, DF, n. 225, 21 out. 2016. Disponível em:
http://www.stf.jus.br/portal/cms/verNoticiaDetalhe.asp?idConteudo=316009. Acesso em: 14 jul. 2020. 41 BARROSO, Luís Roberto; BENVINDO, Juliano Zaiden; OSORIO, Aline. Developments in Brazilian Constitutional Law: The Year 2016 in Review. Blog of the International Journal of Constitutional Law and ConstitutionMaking.org. October $2017 . \quad$ Disponível em: http: / / www.iconnectblog.com/2017/10/developments-in-brazilian-constitutional-law-the-year-2016-inreview/\#_edn3. Acesso em: 13 mar. 2019.

42 Nessa ação, o Partido Rede postulava que o STF determinasse que réus em processos criminais não poderiam ocupar cargos que estivessem na linha sucessória da Presidência da República. Fundamentava que, como a Constituição Federal (art. 86, $\S 1^{\circ}$, inc. I) estabelece que, admitida a denúncia contra o Presidente da República, ele fica afastado do cargo, por uma interpretação analógica, réus em processos criminais não poderiam ser substitutos eventuais do Presidente da República (Supremo Tribunal Federal. Ação de Descumprimento Fundamental n. ${ }^{\circ}$ 402. Relator: Ministro Marco Aurélio. Acompanhamento processual. Disponível em: http: //www.stf.jus.br/portal/processo/verProcessoAndamento.asp?incidente $=4975492$. Acesso em: 10 mar. 2019).

43 BRASIL. Supremo Tribunal Federal. Ação de Descumprimento Fundamental n. ${ }^{\circ} 402$. Medida Cautelar. Decisão monocrática. Relator: Ministro Marco Aurélio. Julgado em 5 dez. 2016. Disponível em: http: //www.stf.jus.br/portal/processo/verProcessoAndamento.asp?incidente $=4975492$. Acesso em: 12 mar. 2019.

44 BRASIL. Supremo Tribunal Federal. Ação de Descumprimento Fundamental n. ${ }^{\circ}$ 402. Medida Cautelar. Decisão monocrática. Relator: Ministro Marco Aurélio. Julgado em 5 dez. 2016. Disponível em: http: //www.stf.jus.br/portal/processo/verProcessoAndamento.asp?incidente $=4975492$. Acesso em: 12 mar. 2019.

45 GARCIA, Gustavo; RAMALHO, Renan. Senado decide descumprir liminar para afastar Renan e aguardar plenário do STF. G1, Brasília, 6 dez. 2016. Disponível em: https://g1.globo.com/politica/noticia/renan- 
O SUPREMO TRIBUNAL FEDERAL NA CRISE POLÍTICA BRASILEIRA DE 2013-2018: SUAS FORÇAS E FRAQUEZAS DIANTE DAS ELITES POLÍTICAS

descumprimento direto da decisão judicial, bem como clara afronta à autoridade da Corte brasileira. Esse era o prenúncio de um episódio em que a fraqueza da Corte seria evidenciada. Após diversas conversas entre ministros da Corte com parlamentares, ${ }^{46}$ a Ministra Cármen Lúcia, então Presidente do STF, se comprometeu a apressar o julgamento de mérito da ação. ${ }^{47}$ Assim, ficou em evidência a fragilidade da Corte diante de elites políticas, bem como que, a depender da decisão do Pleno do STF, poderia se instaurar uma grave crise institucional.

Nesse contexto de grande tensão entre as instituições, em $07 / 12 / 2016$, o Pleno do STF decidiu não referendar a medida liminar, a fim de manter o Senador Renan Calheiros no mandato parlamentar e também como Presidente do Senado Federal, apenas impedindo-o de exercer o cargo de Presidente da República no caso de afastamento do seu titular (STF, ADPF n. ${ }^{\circ}$ 402, 201788). A fragilidade da Corte Constitucional ficou ainda mais evidente porque o STF, poucos meses antes, no julgamento da ação contra o Deputado Eduardo Cunha, havia fixado entendimento oposto (STF, AC n. ${ }^{\circ} 4070,2016^{49}$ ). Assim, pressionado pelas elites políticas, o STF voltou atrás no seu entendimento quando do julgamento do pedido de afastamento do Senador Renan Calheiros, bem como revogou liminar proferida pelo Ministro Marco Aurélio, a qual, inclusive, havia sido acintosamente descumprida pelo Senado.

A força da Corte Constitucional brasileira seria novamente testada no ano seguinte, e mais uma vez sucumbiu.

A Primeira Turma do STF, em 26/09/2017, no julgamento da ação cautelar proposta pela Procuradoria-Geral da República contra o Senador Aécio Neves, decidiu por indeferir o pedido de

senado-decide-nao-cumprir-liminar-e-aguardar-decisao-do-plenario-do-stf.ghtml. Acesso em: 13 mar. 2019.

${ }^{46}$ RAMALHO, Renan. Cármen Lúcia ouve ministros e marca para esta quarta decisão sobre Renan. G1, São Paulo, 6 dez. 2016. Disponível em: https://g1.globo.com/politica/noticia/carmen-lucia-ouve-ministros-emarca-para-esta-quarta-decisao-sobre-renan.ghtml. Acesso em: 13 mar. 2019.

47 PONTES, Felipe. Cármen Lúcia diz que dará urgência à análise da liminar que afastou Renan. EBC Agência Brasil, Brasília, 6 dez. 2016. Disponível em: http://agenciabrasil.ebc.com.br/politica/noticia/2016-12/carmen-lucia-diz-que-dara-urgencia-analise-daliminar-que-afastou-renan. Acesso em: 13 mar. 2019.

48 BRASIL. Supremo Tribunal Federal. Ação de Descumprimento Fundamental n. ${ }^{\circ} 402$. Pretende o afastamento cautelar do exercício da Presidência do Senado Federal, por ser réu em processo penal. Autor: Rede Sustentabilidade. Réu: Presidente da Câmara dos Deputados. Relator: Ministro Marco Aurélio. Julgado em 22 jun. 2017. Diário da Justiça Eletrônico: Brasília, DF, n. 140, public. 27/6/2017. Disponível em: http://www.stf.jus.br/arquivo/cms/noticiaNoticiaStf/anexo/ADPF402Ementa.pdf. Acesso em: 14 jul. 2020.

49 BRASIL. Supremo Tribunal Federal. Ação Cautelar n. ${ }^{\circ}$ 4070. Suspende o mandato do então Deputado Federal Eduardo Cunha, para afastá-lo da presidência da Câmara dos Deputados e do exercício do mandato parlamentar. Autor: Procurador-Geral da República. Réu: Eduardo Cosentino da Cunha. Relator: Ministro Teori Zavascki. Tribunal Pleno. Julgado em 5 mai. 2016. Acórdão eletrônico. Diário da Justiça Eletrônico: Brasília, DF, n. 225, 21 out. 2016. Disponível em: http://www.stf.jus.br/portal/cms/verNoticiaDetalhe.asp?idConteudo=316009. Acesso em: 14 jul. 2020. 
O SUPREMO TRIBUNAL FEDERAL NA CRISE POLÍTICA BRASILEIRA DE 2013-2018: SUAS FORÇAS E FRAQUEZAS DIANTE DAS ELITES POLÍTICAS

FABRÍCIO CASTAGNA LUNARDI

prisão preventiva, mas aplicar as medidas cautelares de "suspensão do exercício das funções parlamentares ou de qualquer outra função pública”; “proibição de contatar qualquer outro investigado ou réu no conjunto dos feitos em tela"; "proibição de se ausentar do País, devendo entregar seus passaportes" e de "recolhimento domiciliar no período noturno" (STF, AC n. ${ }^{\circ} 4327$, $\left.2017^{50}\right)$. Tratava-se, entretanto, de um parlamentar muito influente no Senado e no país, que mais uma vez colocaria em xeque a autoridade da Corte Constitucional brasileira.

Embora houvesse entendimento pacificado do STF no sentido de que a aplicação dessas medidas cautelares ao parlamentar não precisaria de autorização da Casa Legislativa respectiva, o Senado marcou para o dia 03/10/2017 sessão para debater a questão. Assim, sinalizou que poderia descumprir as medidas cautelares fixadas pelo Supremo ao Senador.

Diante da crise institucional que se avizinhava, a Corte brasileira se apressou em pautar o julgamento da $\mathrm{ADI} n .^{\circ} 5526^{51}$, que discutia abstratamente a questão e já tramitava desde 16/05/2016. Entretanto, ainda assim, havia diversos Senadores que pretendiam que o Senado decidisse sobre a questão, mesmo sem esperar pelo julgamento da referida ADI. Diante disso, foi marcada para o dia 2/10/2017 uma reunião entre a Presidente do STF, Ministra Cármen Lúcia, e o Presidente do Senado, Senador Eunício Oliveira. Nesta reunião, a Ministra Cármen Lúcia teria

50 BRASIL. Supremo Tribunal Federal. Ação Cautelar n. ${ }^{\circ}$ 4327. Agravo regimental. Postula a prisão preventiva ou a fixação de medidas cautelares diversas da prisão ao Senador Aécio Neves, e também se questionava se essas medidas deveriam ser deliberadas pela sua Casa Legislativa. Autor: Ministério Público Federal. Réu: Aécio Neves Da Cunha. Relator: Ministro Marco Aurélio, Relator p/ Acórdão: Ministro Roberto Barroso. Primeira Turma. Julgado em 26 set. 2017. Diário da Justiça Eletrônico: Brasília, DF, n. 247, 272017.2 Disponível em: http://www.stf.jus.br/arquivo/cms/noticiaNoticiaStf/anexo/AC4327agravoMMA.pdf. Acesso em: 14 jul. 2020.

51 A ADI 5526 foi ajuizada em 16/5/2016, na qual os partidos Progressista (PP), Social Cristão (PSC) e Solidariedade postulavam que fosse dada interpretação conforme a Constituição para que a aplicação das medidas cautelares, quando impostas a parlamentares, fossem submetidas, em 24 horas, à deliberação da Casa Legislativa respectiva (BRASIL. Supremo Tribunal Federal. Ação Direta de Inconstitucionalidade n. ${ }^{\circ}$ 5526. Julgado parcialmente procedente o pedido. O Poder Judiciário dispõe de competência para impor, por autoridade própria, as medidas cautelares a que se refere o art. 319 do Código de Processo Penal, mas deve se encaminhar à Casa Legislativa a que pertencer o parlamentar, para os fins a que se refere o art. 53 , § $2^{\circ}$, da Constituição, a decisão pela qual se aplique medida cautelar, sempre que a execução desta impossibilitar, direta ou indiretamente, o exercício regular de mandato parlamentar. Requerentes: Partido Progressista - PP; Partido Social Cristão - PSC. Relator p/ acórdão: Ministro Alexandre de Moraes. Julgado em 11 out. 2017. Diário da Justiça Eletrônico: Brasília, DF, n. 159, 7 ago. 2018. Disponível em: http://www.stf.jus.br/arquivo/cms/noticiaNoticiaStf/anexo/ADI5526votoAM.pdf. Acesso em: 14 jul. 2020). Ou seja, pretendiam que fosse aplicada a mesma condicionante estabelecida na Constituição para a hipótese de prisão em flagrante de crime inafiançável. Nesta situação, o art. 53 , § $2^{\circ}$, da CF prevê que os autos deverão ser remetidos à Casa legislativa respectiva para que a maioria dos membros delibere sobre a prisão: “Art. 53. [...] § $2^{\circ}$ Desde a expedição do diploma, os membros do Congresso Nacional não poderão ser presos, salvo em flagrante de crime inafiançável. Nesse caso, os autos serão remetidos dentro de vinte e quatro horas à Casa respectiva, para que, pelo voto da maioria de seus membros, resolva sobre a prisão". 
O SUPREMO TRIBUNAL FEDERAL NA CRISE POLÍTICA BRASILEIRA DE 2013-2018: SUAS FORÇAS E FRAQUEZAS DIANTE DAS ELITES POLÍTICAS

FABRÍCIO CASTAGNA LUNARDI

se comprometido a apressar o julgamento da ADI n. ${ }^{\circ} 5526^{52}$, que discutia abstratamente a questão, e o Senador Eunício Oliveira a adiar no Senado a discussão sobre as medidas cautelares impostas ao Senador Aécio Neves. ${ }^{53}$

Então, em 11/10/2017, o STF, ao julgar a referida ADI, por maioria de 6 a 5, recuou em seu entendimento anterior ${ }^{54}$, para fixar a tese de que o "Poder Judiciário dispõe de competência para impor, por autoridade própria, as medidas cautelares a que se refere o art. 319 do Código de Processo Penal", mas "que se encaminhará à Casa Legislativa a que pertencer o parlamentar", Câmara dos Deputados ou Senado Federal, "para os fins a que se refere o art. 53, $\S 2^{\circ}$, da Constituição, a decisão pela qual se aplique medida cautelar, sempre que a execução desta impossibilitar, direta ou indiretamente, o exercício regular de mandato parlamentar" (STF, ADI n. ${ }^{\circ}$ 5526, $2017^{55}$ ). Vale dizer, aplicadas as medidas cautelares que impliquem restrição

52 BRASIL. Supremo Tribunal Federal. Ação Direta de Inconstitucionalidade $n .{ }^{\circ} 5526$. Julgado parcialmente procedente o pedido. O Poder Judiciário dispõe de competência para impor, por autoridade própria, as medidas cautelares a que se refere o art. 319 do Código de Processo Penal, mas deve se encaminhar à Casa Legislativa a que pertencer o parlamentar, para os fins a que se refere 0 art. 53 , $\S 2^{\circ}$, da Constituição, a decisão pela qual se aplique medida cautelar, sempre que a execução desta impossibilitar, direta ou indiretamente, o exercício regular de mandato parlamentar. Requerentes: Partido Progressista PP; Partido Social Cristão - PSC. Relator p/ acórdão: Ministro Alexandre de Moraes. Julgado em 11 out. 2017. Diário da Justiça Eletrônico: Brasília, DF, n. 159, 7 ago. 2018. Disponível em: http://www.stf.jus.br/arquivo/cms/noticiaNoticiaStf/anexo/ADI5526votoAM.pdf. Acesso em: 14 jul. 2020.

53 CASADO, Letícia; FERNANDES, Talita. Cármen Lúcia se reúne com presidente do Senado para tratar caso Aécio. Folha de São Paulo, São Paulo, 2/10/2017. Disponível em: https: / www1.folha.uol.com.br/poder/2017/10/1923541-carmen-lucia-se-reune-com-presidente-dosenado-para-tratar-caso-aecio.shtml. Acesso em: 13 mar. 2019.

${ }^{54}$ Quando da imposição das medidas cautelares e da suspensão do Deputado Eduardo Cunha do seu mandato, havia um forte movimento popular nas ruas pedindo a sua cassação. No momento do julgamento da ADI 5526, existe um cenário em que a maioria dos membros da Câmara do Deputados e do Senado está sendo investigada, além do próprio Presidente da República Michel Temer. Além disso, no momento deste julgamento pelo STF, está marcada para menos de uma semana depois sessão do Senado para, na prática, definir se cumpre ou não as medidas cautelares impostas pelo STF. Ou seja, o próprio STF está emparedado, ou seja, uma decisão idêntica à que foi tomada no julgamento da ação cautelar em relação ao deputado Eduardo Cunha poderia significar em seu não cumprimento pelo Senado, o que geraria grave crise institucional. Segundo diversas fontes, isso, aliás, teria sido algo que pesou muito no voto de minerva da Ministra Cármen Lúcia, que, neste julgamento, agora como presidente da Corte, tinha maior responsabilidade de manter a estabilidade da relação institucional entre os poderes, razão pela qual desempatou em favor do parlamento, ou seja, decidiu de forma oposta do que havia feito quando do julgamento da ação cautelar 4070, há um ano antes (BRASIL. Supremo Tribunal Federal. Ação Cautelar n. ${ }^{\circ}$ 4070. Suspende o mandato do então Deputado Federal Eduardo Cunha, para afastá-lo da presidência da Câmara dos Deputados e do exercício do mandato parlamentar. Autor: Procurador-Geral da República. Réu: Eduardo Cosentino da Cunha. Relator: Ministro Teori Zavascki. Tribunal Pleno. Julgado em 5 mai. 2016. Acórdão eletrônico. Diário da Justiça Eletrônico: Brasília, DF, n. 225, 21 out. 2016. Disponível em: http://www.stf.jus.br/portal/cms/verNoticiaDetalhe.asp?idConteudo=316009. Acesso em: 14 jul. 2020).

${ }^{55}$ BRASIL. Supremo Tribunal Federal. Ação Direta de Inconstitucionalidade n. ${ }^{\circ}$ 5526. Julgado parcialmente procedente o pedido. 0 Poder Judiciário dispõe de competência para impor, por autoridade própria, as medidas cautelares a que se refere o art. 319 do Código de Processo Penal, mas deve se encaminhar à 
O SUPREMO TRIBUNAL FEDERAL NA CRISE POLÍTICA BRASILEIRA DE 2013-2018: SUAS FORÇAS E FRAQUEZAS DIANTE DAS ELITES POLÍTICAS

FABRÍCIO CASTAGNA LUNARDI

ao mandato parlamentar, os autos do processo devem ser remetidos, dentro de vinte e quatro horas, à Casa Legislativa respectiva, para que, pelo voto da maioria de seus membros, decida se suspende ou não as medidas judiciais aplicadas ao parlamentar. Assim, voltou atrás em relação ao entendimento que havia recentemente sido firmado no julgamento da Ação Cautelar $n .^{\circ} 4070$ (STF, AC 4070, 2016 ${ }^{56}$ ), em 05/05/2016, contra o Deputado Federal Eduardo Cunha.

Essa decisão do STF representava, mais uma vez, o prenúncio da vitória do poder político. Em 17/10/2017, o Senado Federal afastou as medidas cautelares de recolhimento noturno e de afastamento do mandato parlamentar impostas pela Corte ao Senador Aécio Neves ${ }^{57}$.

Além dessas formas de descumprimento direto e de pressão da classe política em relação à corte constitucional, também não são incomuns medidas políticas para contornar os impactos das decisões judiciais.

O STF, ao julgar a ADI n. ${ }^{\circ} 4650$, em 17/09/2015, decidiu por proibir doações de pessoas jurídicas a candidatos $^{58}$, ou seja, reduziu muito as possibilidades de financiamento privado de campanhas políticas.

As respostas do Congresso Nacional não tardariam. A fim de contornar a deficiência de recursos para as campanhas, diversas foram as propostas legislativas para encontrar saídas aos impactos gerados pela decisão do STF. Nesse contexto, foi editada a Lei n. ${ }^{\circ} 13.487$, de 06/10/2017, que criou o Fundo Especial de Financiamento de Campanha (FEFC). As estimativas

Casa Legislativa a que pertencer o parlamentar, para os fins a que se refere 0 art. 53 , $\S 2^{\circ}$, da Constituição, a decisão pela qual se aplique medida cautelar, sempre que a execução desta impossibilitar, direta ou indiretamente, o exercício regular de mandato parlamentar. Requerentes: Partido Progressista PP; Partido Social Cristão - PSC. Relator p/ acórdão: Ministro Alexandre de Moraes. Julgado em 11 out. 2017. Diário da Justiça Eletrônico: Brasília, DF, n. 159, 7 ago. 2018. Disponível em: http://www.stf.jus.br/arquivo/cms/noticiaNoticiaStf/anexo/ADI5526votoAM.pdf. Acesso em: 14 jul. 2020.

56 BRASIL. Supremo Tribunal Federal. Ação Cautelar n. ${ }^{\circ}$ 4070. Suspende o mandato do então Deputado Federal Eduardo Cunha, para afastá-lo da presidência da Câmara dos Deputados e do exercício do mandato parlamentar. Autor: Procurador-Geral da República. Réu: Eduardo Cosentino da Cunha. Relator: Ministro Teori Zavascki. Tribunal Pleno. Julgado em 5 mai. 2016. Acórdão eletrônico. Diário da Justiça Eletrônico: Brasília, DF, n. 225, 21 out. 2016.

${ }^{57}$ AGẾNCIA SENADO. Plenário rejeita medidas cautelares contra Aécio Neves e senador retoma mandato. Senado notícias, Brasília, 17 out. 2017. Disponível em: https://www12.senado.leg.br/noticias/materias/2017/10/17/senado-devolve-mandato-a-aecio-neves.

Acesso em: 13 mar. 2019.

${ }^{58}$ BRASIL. Supremo Tribunal Federal. Ação Direta de Inconstitucionalidade n. ${ }^{\circ} 4650$. Julgado parcialmente procedente o pedido. Declarou a inconstitucionalidade dos dispositivos legais que autorizavam as contribuições de pessoas jurídicas às campanhas eleitorais. Com relação às pessoas físicas, as contribuições ficam reguladas pela lei em vigor. Autor: Conselho Federal da Ordem dos Advogados do Brasil. Requeridos: Congresso Nacional; Presidente da República. Relator: Ministro Luiz Fux. Tribunal Pleno. Julgado em 17 set. 2015. Diário da Justiça Eletrônico: Brasília, DF, n. 34, 24 fev. 2016. Disponível em: http://www.stf.jus.br/portal/cms/verNoticiaDetalhe.asp?idConteudo=300015. Acesso em: 14 jul. 2020. 
O SUPREMO TRIBUNAL FEDERAL NA CRISE POLÍTICA BRASILEIRA DE 2013-2018: SUAS FORÇAS E FRAQUEZAS DIANTE DAS ELITES POLÍTICAS

são que o valor desse fundo, constituído de verbas públicas, seja, para as campanhas de 2018, no importe de $\mathrm{R} \$ 1,7$ bilhão ${ }^{59}$. Além disso, houve um aumento considerável do valor destinado ao Fundo Partidário (constituído de verba pública), chegando-se ao importe de R\$ 888 milhões ${ }^{60}$, embora houvesse pressão do Congresso Nacional por um valor ainda maior. Assim, a classe política encontrou uma alternativa para contornar a redução de recursos de campanha decorrente da decisão do Supremo de proibir o financiamento de campanhas eleitorais por pessoas jurídicas, mas sobrecarregou ainda mais os cofres públicos.

Além das ameaças de descumprimento das decisões do STF, seja de forma direta ou indireta, expressa ou velada, a classe política também tem promovido medidas de sobreposição às decisões da Corte e também de retaliação, como as a seguir descritas.

A sobreposição do Congresso a decisões do STF, através da reversão, ficou evidente no caso da vaquejada. ${ }^{61}$

O STF, em 06/10/2016, julgou procedente a Ação Direta de Inconstitucionalidade n. ${ }^{\circ}$ 4.983, proposta pelo Procurador-Geral da República contra a Lei n. ${ }^{\circ} 15.299 / 2013$ do Estado do Ceará, que regulamentava a vaquejada como prática desportiva e cultural no âmbito deste Estado. 0 principal fundamento foi o de que o inciso VII do $\S 1^{\circ}$ do artigo 225 da Constituição Federal veda as práticas que submetam animais à crueldade, e a denominada vaquejada implicaria "crueldade manifesta", sendo incompatível com a Constituição Federal ${ }^{62}$.

Então, como resposta à decisão do STF, o Congresso Nacional, em 06/06/2017, aprovou a Emenda Constitucional n. ${ }^{\circ} 96$, que permite "as práticas desportivas que utilizem animais, desde que sejam manifestações culturais". ${ }^{63}$

${ }^{59}$ ENTENDA o novo fundo público para campanhas eleitorais aprovado na Câmara. BBC BRASIL, 4/10/2017. Disponível em: http://www.bbc.com/portuguese/brasil-41507850. Acesso em: 13 mar. 2019.

${ }^{60}$ GOVERNO reserva quase R\$ 900 milhões para fundo partidário. G1, São Paulo, 4 set. 2017. Disponível em: $\quad$ http://g1.globo.com/jornal-nacional/noticia/2017/09/governo-reserva-quase-r-900-milhoes-parafundo-partidario.html. Acesso em: 13 mar. 2019.

${ }^{61}$ De acordo com a Lei n 15.299, de 8 de janeiro de 2013, do Estado do Ceará, "considera-se vaquejada todo evento de natureza competitiva, no qual uma dupla de vaqueiro a cavalo persegue animal bovino, objetivando dominá-lo" (art. $2^{\circ}$, caput).

62 BRASIL. Supremo Tribunal Federal. Ação Direta de Inconstitucionalidade $n^{\circ} 4983$. Foi declarada a inconstitucionalidade da Lei Estadual questionada, para vedar a denominada vaquejada. Requerente: Procurador-Geral da República. Requeridos: Governador do Estado do Ceará; Assembleia Legislativa do Estado do Ceará. Relator: Ministro Marco Aurélio. Tribunal Pleno. Julgado em 6 out. 2016. Diário da Justiça Eletrônico: Brasília, DF, n. 87, 27 abr. 2017. Disponível em: http://redir.stf.jus.br/paginadorpub/paginador.jsp?docTP=TP\&docID=12798874. Acesso em: 14 jul. 2020.

${ }^{63}$ A referida Emenda Constitucional (EC 96/2017) acrescentou o parágrafo $7^{\circ}$ ao artigo 225 da Constituição Federal, com a seguinte redação: “§ $7^{\circ}$ Para fins do disposto na parte final do inciso VII do $\S 1^{\circ}$ deste artigo, não se consideram cruéis as práticas desportivas que utilizem animais, desde que sejam manifestações culturais, conforme o $\$ 1^{\circ}$ do art. 215 desta Constituição Federal, registradas como bem de natureza imaterial integrante do patrimônio cultural brasileiro, devendo ser regulamentadas por lei 
Em 13/06/2017, o Fórum Nacional de Proteção e Defesa Animal ajuizou a Ação Direta de Inconstitucionalidade $n \cdot{ }^{\circ} 5728$ perante o STF, para questionar a referida Emenda Constitucional ${ }^{64}$. Um dos argumentos da associação autora é o de que "a emenda questionada teve por motivação contornar a declaração de inconstitucionalidade de lei do Ceará que legalizava a prática da vaquejada, em decisão proferida pelo STF em outubro de 2016"65. Além disso, a Procuradoria-Geral da República, em 12/09/2017, também ajuizou a ADI n. ${ }^{\circ} 5772^{66}$, com o mesmo objeto.

Apesar do claro objetivo de reverter a decisão do STF, este, até o momento, não apreciou os pedidos de medida cautelar formulados nas referidas ADIs (STF, ADI $n^{\circ} 5728,2018$; STF, ADI $n^{\circ}$ 5772, 2018). E talvez essa inércia seja motivada pela estratégia de não haver desgaste da Corte com o Congresso Nacional, pois o STF já tinha decidido o caso em outra ADI que questionava lei estadual.

As retaliações também têm sido um instrumento utilizado pela classe política em meio à crise que se instalou no cenário político brasileiro, diante da investigação criminal no STF em relação a diversas autoridades da República.

Em 05/07/2016, o Senador Renan Calheiros, alvo de diversas investigações criminais no STF, propôs o denominado Projeto de Lei de Abuso de Autoridade (Projeto de Lei do Senado n. ${ }^{\circ}$ 280/2016), que, apesar do nome, mais parecia uma tentativa de limitar as investigações criminais e a atuação do Ministério Público e do Judiciário. Em que pese o jogo retórico com o nome desse projeto de lei (Projeto de Lei do “Abuso de Autoridade”), houve forte desaprovação do público em geral, com $98,34 \%$ (noventa e oito inteiros e trinta e quatro centésimos por cento)

específica que assegure o bem-estar dos animais envolvidos". A parte final do inciso VII do $\S 1^{\circ}$ a que se refere o dispositivo diz respeito à "vedação das práticas" que "submetam os animais a crueldade", ou seja, a EC 96/2017 trouxe uma exceção a essa vedação.

${ }^{64}$ BRASIL. Supremo Tribunal Federal. Ação Direta de Inconstitucionalidade $n^{\circ} 5728$. Postula a declaração de inconstitucionalidade da Emenda Constitucional n. ${ }^{\circ}$ 96, que permite "as práticas desportivas que utilizem animais, desde que sejam manifestações culturais". Requerente: Fórum Nacional de Proteção e Defesa Animal. Requerido: Mesa da Câmara dos Deputados. Acompanhamento Processual. Disponível em: http: / / stf.jus.br/portal/processo/verProcessoAndamento.asp?numero=5728\&classe=ADI\&origem=AP\&recur so=0\&tipoJulgamento $=M$. Acesso em: 6 jun. 2020.

65 BRASIL. Supremo Tribunal Federal. ADI questiona emenda constitucional que permite a prática de vaquejada. Notícias STF, Brasília, 3 jul. 2017. Disponível em: http://stf.jus.br/portal/cms/verNoticiaDetalhe.asp?idConteudo=348571. Acesso em: 6 jun. 2020.

${ }^{66}$ BRASIL. Supremo Tribunal Federal. Ação Direta de Inconstitucionalidade $n^{\circ}{ }^{5772}$. Postula a declaração de inconstitucionalidade da Emenda Constitucional n. ${ }^{\circ}$ 96, que permite as práticas desportivas que utilizem animais, desde que sejam manifestações culturais. Requerente: Procurador-Geral da República. Requeridos: Presidente da República; Congresso Nacional. Acompanhamento Processual. Disponível em: http://portal.stf.jus.br/processos/detalhe.asp?incidente=5259991. Acesso em: 6 jun. 2020. 
O SUPREMO TRIBUNAL FEDERAL NA CRISE POLÍTICA BRASILEIRA DE 2013-2018: SUAS FORÇAS E FRAQUEZAS DIANTE DAS ELITES POLÍTICAS

FABRÍCIO CASTAGNA LUNARDI

rejeição popular ${ }^{67}$. Diante da forte pressão popular, mas firme no propósito de retaliar o Judiciário, o Senado, em 26/04/2017, decidiu aprovar um substitutivo ao referido Projeto de Lei, de autoria do Senador Roberto Requião ${ }^{68}$, que mantém a maioria das disposições iniciais, mas retira do texto o que era muito criticado dentre juristas, o chamado "crime de hermenêutica". 69

Em 10/11/2016, o então Presidente do Senado, Renan Calheiros, instalou comissão para investigar os chamados "supersalários", tendo como alvo membros do Poder Judiciário, ${ }^{70}$ o que foi visto por presidentes de tribunais e associações de magistrados e membros do Ministério Público como mais uma medida de retaliação, para tentar desgastar a imagem do Poder Judiciário perante a sociedade. ${ }^{71}$ Sem se adentrar na questão de fundo da medida, certamente se tratava de mais uma forma de retaliação, mas que encontraria apoio popular.

Assim, em meio à crise política que se iniciou em 2013, é possível observar uma classe política acuada e uma Corte Constitucional que, na prática, intervém analisando os seus próprios limites e as possibilidades de efetivação das suas decisões.

67 SENADO FEDERAL. Consulta Pública: Projeto de Lei do Senado $\mathrm{n}^{\circ}$ 280, de 2016. Disponível em: https://www25.senado.leg.br/web/atividade/materias/-/materia/126377. Acesso em: 11 mar. 2019.

${ }^{68}$ SENADO FEDERAL. Parecer da Comissão de Constituição, Justiça e Cidadania, sobre os Projetos de Lei do Senado $n^{\circ} 280$, de 2016, do Senador Renan Calheiros, e $n^{\circ} 85$, de 2017, do Senador Randolfe Rodrigues, que definem os crimes de abuso de autoridade e dão outras providências. Disponível em: http://legis.senado.leg.br/sdleg-getter/documento?dm=5239240\&disposition=inline. Acesso em: $13 \mathrm{mar}$. 2019.

69 AGÊNCIA SENADO. Senado aprova projeto que altera Lei de Abuso de Autoridade. Senado Notícias, Brasília, $28 \quad$ abr. $2017 . \quad$ Disponível https://www12.senado.leg.br/noticias/materias/2017/04/26/senado-aprova-projeto-que-altera-lei-deabuso-de-autoridade. Acesso em: 11 mar. 2019.

70 SARDINHA, Edson. De olho no Judiciário, Renan instala comissão para frear supersalários. Congresso em foco, Brasília, 10 nov. 2016. Disponível em: http://congressoemfoco.uol.com.br/noticias/de-olho-nojudiciario-renan-instala-comissao-para-frear-supersalarios $/$. Acesso em: $1^{\circ} \mathrm{mar} .2019$.

71 "Presidentes de Tribunais de Justiça reunidos nesta segunda-feira, 14, com a presidente do Supremo Tribunal Federal (STF), ministra Cármen Lúcia, viram como uma 'retaliação' a iniciativa do presidente do Senado, Renan Calheiros (PMDB-AL), de instalar uma comissão especial para levantar os supersalários do Judiciário e do Ministério Público. Entidades representativas de juízes também reagiram à medida. [...] Presidentes de Tribunais de Justiça reunidos nesta segunda-feira, 14, com a presidente do Supremo Tribunal Federal (STF), ministra Cármen Lúcia, viram como uma 'retaliação' a iniciativa do presidente do Senado, Renan Calheiros (PMDB-AL), de instalar uma comissão especial para levantar os supersalários do Judiciário e do Ministério Público. Entidades representativas de juízes também reagiram à medida." (MOURA, Rafael Moraes; BONFIM, Isabela. TJs veem retaliação em comissão de supersalários. Estadão, Brasília, 16 nov. 2016. Disponível em: http://politica.estadao.com.br/noticias/geral,tjs-veem-retaliacaoem-comissao-de-supersalarios, 10000088443 . Acesso em: $1^{\circ}$ mar. 2019) 
Se as teses de "supremocracia"72 ou de "ditadura do Poder Judiciário"73 não são condizentes com esse contexto, as teorias constitucionais contemporâneas que propõem um sistema fraco ou forte de judicial review, já analisadas, são subcomplexas para investigar essa questão. Considerando a complexidade da relação da Corte Constitucional com os demais Poderes Constituídos e com as elites políticas, seja quando as enfrenta ou quando lhes é subserviente, a sua independência para decidir e a sua efetiva capacidade de impor as suas decisões são muito mais limitadas do que as teorias tradicionais de direito constitucional sugerem.

Os casos acima citados deixam em aberto diversas questões: Qual é a real capacidade de a Corte Constitucional brasileira implementar as suas decisões? Como atua para angariar capital político, a fim de efetivar as suas decisões? Quais são as variáveis que devem ser consideradas nos diferentes casos, quando o STF se sobrepõe e quando sucumbe às elites políticas? Quais são as estratégias que a Corte brasileira pode utilizar para impor as suas decisões contra as elites políticas? Quais são as respostas das elites políticas às decisões que the são desfavoráveis e quais as estratégias que se utilizam para descumprir, direta ou indiretamente, para se evadir, retaliar ou reverter as decisões judiciais? Enfim, de onde vem a força e quais são as fraquezas da Corte Constitucional brasileira?

\section{AS COMPLEXAS ESTRATÉGIAS JUDICIAIS PARA A EFETIVAÇÃO DAS DECISÕES E AS ESTRATÉGIAS POLÍTICAS DE DESCUMPRIMENTO: REFLEXÕES À LUZ DE ESTUDOS COMPARADOS}

Nas situações em que a decisão da corte constitucional não atinge questões constitucionais estruturais nem interesses de elites políticas ou do governo, comumente não há grandes preocupações com a sua efetivação. Além disso, há casos em que a corte constitucional conta com um grande suporte político. No entanto, as situações de interesse para esta investigação são aquelas em que existe um ambiente difícil, quando há algum impacto relevante e contrário às elites políticas. Então, a questão que se coloca é como as elites políticas buscam

72 VILHENA, Oscar. Supremocracia. Revista de Direito do Estado, Rio de Janeiro, a. 3, n. 12, p. 55-75, out.-dez. 2008. p. 59. Disponível em: https://www.scielo.br/pdf/rdgv/v4n2/a05v4n2.pdf. Acesso em: 14 jul. 2020.

73 DELMANTO, Roberto. A ditadura do Judiciário. Migalhas, 15 mar. 2018. Disponível em: http: / / www.migalhas.com.br/dePeso/16,MI276327,101048-A+ditadura+do+Judiciario. Acesso em: 10 mar. 2019. 
descumprir, se evadir e contornar decisões judiciais e retaliar o tribunal constitucional. ${ }^{74}$ Nessas situações, de que forma os tribunais constitucionais podem angariar apoio de outras elites políticas e outros atores, como o público em geral e as instituições internacionais, para fazer frente a esses instrumentos de pressão de elites políticas? Quais são as ferramentas que utilizam? Essas questões, que comumente passam à margem das discussões jurídico-normativas, acabam sendo centrais na tomada de decisão dos tribunais constitucionais.

Do ponto de vista político-institucional, a revisão judicial é algo que pode criar uma tensão política, sobretudo quando derruba iniciativas políticas consideradas importantes por uma parte significativa das elites políticas. ${ }^{75}$ Quando a corte constitucional decide sobre questões estruturais, tais como as relativas à separação dos poderes ou à distribuição de poder político no âmbito federal, estadual e/ou municipal, há maior risco de descumprimento ou retaliação por parte dos atores políticos. ${ }^{76}$ Também haverá maior possibilidade de descumprimento quando as decisões contrariarem os interesses de certos políticos ou partidos com muito poder. Assim, por exemplo, uma decisão que limite o poder presidencial, que reduza prerrogativas parlamentares ou que, em processo criminal, determine a restrição da liberdade ou de direitos de determinado político certamente encontrará pela frente possibilidade de descumprimento ou, ao menos, de retaliação.

Nessas situações, em que julgamentos do tribunal constitucional afetam diretamente interesses governistas ou de elites políticas, a sua efetividade poderá ficar comprometida, podendo o exercício da revisão judicial se tornar algo perigoso para a própria corte e para o cumprimento das suas decisões. Com efeito, esses atores políticos, se pressionados, atuarão para descumprir, se evadir ou contornar a decisão judicial, ou, ainda, impor represálias, o que pode enfraquecer o tribunal constitucional. Ocorre o chamado efeito backlash, consistente em

74 Em situações extremas, o descontentamento do governo ou de atores políticos com a corte constitucional pode ser tão grande que eles podem tentar fechar a corte, destituir seus membros ou reduzir drasticamente as suas competências. No entanto, como referem Gretchen Helmke e Jeffrey Staton, não haveria incentivos para destituir os membros de um tribunal quando o governo e atores políticos relevantes podem, com menor custo, pode simplesmente ignorar uma decisão (HELMKE, Gretchen; STATON, Jeffrey K. The Puzzling Judicial Politics of Latin America: A Theory of Litigation, Judicial Decisions, and Interbranch Conflict. In: HELMKE, Gretchen; RÍOS-FIGUEROA, Julio (Org.). Courts in Latin America. New York: Cambridge University Press, 2011. p. 306-331. p. 327. Disponível em: https://scholarblogs.emory.edu/jeffreystaton/files/2018/03/puzzles.pdf. Acesso em: 14 jul. 2020).

75 TUSHNET, Mark. Preserving Judicial Independence in Dominant Party States. New York Law School Law Review, v. 60, n. 1, p. 107-124, 2016. p. 109. Disponível em: https: //digitalcommons.nyls.edu/cgi/viewcontent.cgi?article=1149\&context=nyls_law_review. Acesso em: 14 jul. 2020.

${ }^{76}$ LANDAU, David. Political support and structural constitutional law. Alabama Law Review, Tuscaloosa, Alabama, v. 67, p. 1069-1124, 2016. p. 1074. Disponível em: https://papers.ssrn.com/sol3/papers.cfm?abstract_id=2907084. Acesso em: 14 jul. 2020. 
reações adversas à atuação judicial, um contra-ataque político ao resultado das decisões da corte constitucional ${ }^{77}$.

O descumprimento direto ocorre quando há a recusa expressa ou o fracasso na efetivação de uma decisão judicial. ${ }^{78}$ Essa forma de descumprimento é a que mais fragiliza a corte constitucional, pois coloca em xeque a própria autoridade das suas decisões, podendo gerar verdadeira crise institucional. Por isso, comumente, quando cortes constitucionais precisam tomar decisões contrárias aos interesses de elites políticas, ou se utilizam de um capital político acumulado e/ou da opinião pública ao seu favor, ou, então, adotam uma postura de autocontenção.

As represálias também constituem um recurso muito utilizado pelas classes políticas contra o tribunal constitucional, seja para reduzir garantias de independência, prerrogativas do cargo, direitos relativos à remuneração, ou para gerar desgaste na imagem do Judiciário perante a população em geral.

Entretanto, o descumprimento direto e as represálias não são os únicos problemas que enfrentam as cortes constitucionais. Há possibilidade de que a decisão judicial seja formalmente cumprida, mas os atores políticos encontrem outro caminho para conseguirem os fins almejados, desviando ou contornando a decisão. É o que a doutrina estadunidense em geral chama de saída “hidráulica”, que consiste em, diante da proibição de certa conduta ou havendo certa forma de regulação, o ente político responder mudando para outro caminho. Isto, pragmaticamente, é bastante comum ocorrer no âmbito do direito fiscal, do direito penal, bem como diante de reformas no financiamento de campanha ou na lei eleitoral. ${ }^{79}$ Embora as saídas hidráulicas sejam analisadas em diversos contextos há mais tempo, são bem mais recentes e ainda muito escassos os estudos sobre como um juiz se antecipa a uma resposta hidráulica e como isso pode afetar a sua tomada decisão. ${ }^{80}$

77 MARMELSTEIN, George. Efeito Backlash da Jurisdição Constitucional: reações políticas ao ativismo judicial. Bolonha: 2016. Texto-base de palestra proferida durante o Terceiro Seminário Ítalo-Brasileiro. Disponível em: https://www.academia.edu/35675035/Efeito_Backlash_da_Jurisdi\%C3\%A7\%C3\%A3o_Constitucinal. Acesso em: 3 jun. 2020. p. 3.

78 LANDAU, David. Political support and structural constitutional law. Alabama Law Review, Tuscaloosa, Alabama, v. 67, p. 1073. Disponível em: https://papers.ssrn.com/sol3/papers.cfm?abstract_id=2907084. Acesso em: 14 jul. 2020.

79 LANDAU, David. Political support and structural constitutional law. Alabama Law Review, Tuscaloosa, Alabama, v. 67, p. 1069-1124, 2016. p. 1075. Disponível em: https://papers.ssrn.com/sol3/papers.cfm?abstract_id=2907084. Acesso em: 14 jul. 2020.

80 MILLIGAN, Luke M. Congressional End-Run: The Ignored Constraint on Judicial Review. Georgia Law Review, v. 45, n. 1, p. 211-274, Fall 2010. pp. 252-254. Disponível em: https://papers.ssrn.com/sol3/papers.cfm?abstract_id=1709405. Acesso em: 14 jul. 2020. 
Apesar da variada terminologia proposta por estudiosos das respostas legislativas a uma revisão judicial "indesejada”, Luke Milligan mostra que cada uma das restrições do Congresso sobre a revisão judicial abordada pela literatura pode ser classificada como um freio (curb) ou uma sobreposição (override). ${ }^{81} \mathrm{O}$ freio (curbing) seria, segundo o autor, uma resposta punitiva à revisão judicial adversa, um ato formal do parlamento destinado a limitar a independência do tribunal constitucional, para garantir que futuras decisões sejam proferidas de acordo com as preferências do Congresso. Esses freios seriam indiretos e assimétricos, destinando-se a negar aos juízes certos poderes ou independência para casos futuros. Seriam exemplos de freios a utilização do Senado para confirmar a indicação de certos juízes que comporão tribunais; emendas constitucionais para mudar a estrutura ou o procedimento do tribunal; impeachment de juízes; retirada da competência do tribunal para apreciar determinadas matérias; alteração do processo de seleção e remoção de juízes; exigência de maiorias extraordinárias para declarações de inconstitucionalidade; instrumentos para tornar o tribunal "mais representativo" (aumentando as indicações políticas); retirada do poder de revisão judicial; cortes no orçamento; alterações do tamanho do tribunal. Além disso, o autor também aponta como exemplos desses freios (curbs) o poder do Congresso para congelar os salários dos juízes, ajustar o orçamento em relação ao pagamento de pessoal, exigir o dever de autocontenção judicial, coletar e publicar informações depreciativas sobre juízes e especificar o número de votos necessários para exercer o poder de revisão judicial. ${ }^{82}$

A sobreposição (override), por sua vez, seria, segundo Milligan, o poder de anular os atos de revisão judicial. Ocorreria quando o Congresso sobrepõe a sua própria interpretação da constituição à da corte constitucional. Para o autor, a sobreposição poderia ocorrer de duas formas, ou por emenda constitucional, ou quando o Congresso desconsiderasse, por ação ou omissão, qualquer interpretação não desejada. Para o autor, esse segundo tipo de substituição evocaria a observação de Hamilton de que o Judiciário "pode verdadeiramente dizer que não tem força nem vontade, mas sim um juízo". ${ }^{83}$

\footnotetext{
81 MILLIGAN, Luke M. Congressional End-Run: The Ignored Constraint on Judicial Review. Georgia Law Review, v. 45, n. 1, p. 211-274, Fall 2010. pp. 231/232. Disponível em: https://papers.ssrn.com/sol3/papers.cfm?abstract_id=1709405. Acesso em: 14 jul. 2020.

82 MILLIGAN, Luke M. Congressional End-Run: The Ignored Constraint on Judicial Review. Georgia Law Review, v. 45, n. 1, p. 211-274, Fall 2010. pp. 233/234. Disponível em: https: //papers.ssrn.com/sol3/papers.cfm?abstract_id=1709405. Acesso em: 14 jul. 2020.

83 Tradução livre: MILLIGAN, Luke M. Congressional End-Run: The Ignored Constraint on Judicial Review. Georgia Law Review, v. 45, n. 1, p. 211-274, Fall 2010. pp. 236/237. Disponível em: https://papers.ssrn.com/sol3/papers.cfm?abstract_id=1709405. Acesso em: 14 jul. 2020.
} 
Milligan está tratando do caso estadunidense, de modo que não se pode pretender aplicar essas formas de freio e de sobreposição, em termos de direito comparado, sem a necessária compatibilização com o contexto institucional e político do país que se considera. Por exemplo, no Brasil, as emendas constitucionais também podem ser uma forma de sobreposição, mas é preciso lembrar que o STF pode fazer a revisão judicial da emenda constitucional tendo como paradigma as chamadas "cláusulas pétreas". ${ }^{44}$ No entanto, essas formas de freios e de sobreposição podem, com as devidas ressalvas contextuais, ser objeto de investigação também em outros países. Aliás, como já se pôde observar no subitem anterior, muitas delas já foram e estão sendo utilizadas, no Brasil, pelas elites políticas em face do STF.

É claro que essas tentativas de contornar a decisão judicial comumente são acompanhadas por respostas do Poder Judiciário, que podem buscar fechar as saídas para o descumprimento ou aumentar os custos para outras rotas alternativas pelas quais os atores políticos tentam desviar. Nos EUA, estudiosos do tema têm recentemente desenvolvido a chamada doutrina antievasão, que procura criar mecanismos para fechar os caminhos deixados abertos pelas regras existentes, ou seja, para evitar que ocorra o cumprimento formal da decisão mediante desvios finalísticos, em que os seus destinatários buscam rotas de fuga indevidas $^{85}$.

Ocorre que, para a corte constitucional, talvez não seja estrategicamente aconselhável a utilização desses mecanismos antievasão em determinados casos. Ao utilizar esses instrumentos, precisa admitir, em alguma medida, que as suas decisões estão sujeitas a descumprimento, ou seja, que é possível o direito ceder diante do poder. Assim, é preciso considerar os impactos que esses mecanismos podem ter sobre o direito constitucional. Além disso, para o tribunal constitucional, utilizar essas doutrinas em suas decisões implica reconhecer, em alguma medida, a má-fé dos membros dos outros Poderes Constituídos ${ }^{86}$, e isso pode abalar a sua relação com eles. A utilização desses mecanismos pode, ainda, levar a corte a "legislar", pois é preciso prever possíveis condutas futuras de descumprimento e dizer como o outro órgão terá de se

84 ARGUELHES, Diego Werneck; RIBEIRO, Leandro Molhano. Preferências, Estratégias e Motivações: Pressupostos institucionais de teorias sobre comportamento judicial e sua transposição para o caso brasileiro. Revista Direito e Práxis, Rio de Janeiro, v. 4, n. 7, p. 85-121, 2013. p. 110. Disponível em: https://www.e-publicacoes.uerj.br/index.php/revistaceaju/article/view/7503/6366. Acesso em: 14 jul. 2020.

85 LANDAU, David. Political support and structural constitutional law. Alabama Law Review, Tuscaloosa, Alabama, v. $67, \quad$ p. 1069-1124, 2016. p. 1079. Disponível em: https://papers.ssrn.com/sol3/papers.cfm?abstract_id=2907084. Acesso em: 14 jul. 2020.

86 DENNING, Brannon P.; KENT, Michael B. Jr. Anti-Anti-Evasion in Constitutional Law. Florida State University Law Review, v. 41, n. 2, p. 397-434, Winter 2014. p. 420. Disponível em: https://ir.law.fsu.edu/lr/vol41/iss2/3/. Acesso em: 14 jul. 2020. 
comportar, o que pode abrir um outro flanco para críticas à atuação judicial. Nesse ínterim, os instrumentos para impedir descumprimentos implicam determinações adicionais que talvez sejam desnecessárias, que podem tornar a decisão judicial ainda mais polêmica ou, ainda, que também sejam contornadas, porque dificilmente conseguirá a corte constitucional fechar todas as saídas. Por fim, se as elites políticas utilizarem mecanismos para contornar a decisão judicial, evadindo-se dela, talvez a evasão não gere tantos impactos negativos para a autoridade da corte constitucional quanto um descumprimento direto.

Assim, quando a corte constitucional toma uma decisão e analisa a conjuntura política para assegurar que ela seja cumprida, ou deixa algumas saídas abertas para os órgãos políticos, esse "é um tipo de avaliação de risco que procura obter precauções ótimas (em vez de máximas)", como apontam Brannon Denning e Michael Kent ${ }^{87}$.

Quando se fala em riscos de descumprimento, direto ou indireto, é preciso ainda considerar um complexo de variáveis, que dependem sobretudo do contexto institucional e político de determinado país em dado tempo. Por exemplo, instituições e atores políticos mais fracos terão menos condições de repelir ou contornar decisões judiciais do que aqueles com maior poder político.

Além disso, as cortes constitucionais terão mais facilidade para obter êxito no cumprimento das suas decisões quando contarem com o apoio de outros políticos, de outras instituições ou de grupos da sociedade civil, que podem fazer pressão para que a decisão seja efetivada. Assim, o nível de apoio político desses setores ao tribunal constitucional é uma variável importante na própria tomada de decisão, quando ela pode contrariar interesses de elites políticas ${ }^{88}$.

Se o tribunal constitucional conseguir obter apoio popular, aumentará os custos políticos para aqueles que pretendam descumprir ou evadir-se à decisão judicial. Assim, a corte constitucional pode acumular capital político ao longo do tempo. Nesse ponto, a agenda de direitos humanos, por exemplo, costuma servir para o tribunal constitucional angariar capital político diante do público e de organismos internacionais. Ações envolvendo igualdade de oportunidades e igualdade de gênero comumente são acompanhadas por grupos ativistas, com

87 DENNING, Brannon P.; KENT, Michael B. Jr. Anti-Anti-Evasion in Constitutional Law. Florida State University Law Review, v. 41, n. 2, p. 397-434, Winter 2014. p. 432. Disponível em: https: //ir.law.fsu.edu/lr/vol41/iss2/3/. Acesso em: 14 jul. 2020.

88 LANDAU, David. Political support and structural constitutional law. Alabama Law Review, Tuscaloosa, Alabama, v. 67, p. 1069-1124, 2016. pp. 1071/1072. Disponível em: https://papers.ssrn.com/sol3/papers.cfm?abstract_id=2907084. Acesso em: 14 jul. 2020. 
alta capacidade de mobilização, e, quando a corte constitucional decide favoravelmente a esses grupos, costuma obter muito capital político.

De outro lado, decisões sobre questões institucionais estruturais não possuem o mesmo engajamento popular. David Landau confirma essas afirmações citando exemplos de casos julgados pelas Cortes Colombiana, Mexicana e Estadunidense e a sua repercussão popular. Segundo o autor, recentes defesas da revisão judicial têm se concentrado no papel do tribunal constitucional como um mecanismo de "alarme de incêndio", ou seja, as decisões judiciais podem servir para alertar o público de que os atores políticos estão extrapolando e, portanto, devem se mobilizar e prestar mais atenção às ações dos políticos. ${ }^{89}$

Uma estratégia por vezes utilizada pelos tribunais constitucionais, ao decidir questões estruturais, é o desenvolvimento argumentativo acerca de um conjunto de princípios constitucionais que estão na consciência popular. A esse respeito, Landau exemplifica com o caso do Tribunal Constitucional Colombiano, em que a decisão que impediu o Presidente do país de legislar por decretos foi fundamentada em argumentos como as violações a direitos humanos e os abusos ocorridos em momento pretérito pelos governos em contextos de estado de emergência. ${ }^{90}$

Entretanto, a revisão judicial em questões estruturais tende a ser modesta, não somente no sentido do impacto que pode causar no funcionamento das instituições, mas também considerando até onde pode positivamente chegar. Como aponta David Landau, ainda que tente transformar o comportamento burocrático, a decisão judicial centra-se em torno da provisão de algum conjunto particular de serviços, em vez de ser de âmbito mais geral. Mesmo se não houvesse restrições à atuação judicial, seria improvável que tribunais empreendessem uma intervenção estrutural generalizada na legislatura ou em outro ramo do governo. ${ }^{91}$

Analisando a questão do ponto de vista do direito constitucional comparado, David Landau aponta que a revisão judicial ocorre, na prática, de forma diversa da que é concebida pelas teorias constitucionais clássicas. Ressalta que, em questões estruturais, a revisão judicial será mais efetiva quando possui suporte externo significativo em outros lugares do sistema

89 LANDAU, David. Political support and structural constitutional law. Alabama Law Review, Tuscaloosa, Alabama, v. 67, p. 1069-1124, 2016. p. 1121. Disponível em: https://papers.ssrn.com/sol3/papers.cfm?abstract_id=2907084. Acesso em: 14 jul. 2020.

90 LANDAU, David. Political support and structural constitutional law. Alabama Law Review, Tuscaloosa, Alabama, v. 67, p. 1069-1124, 2016. p 1122. Disponível em: https://papers.ssrn.com/sol3/papers.cfm?abstract_id=2907084. Acesso em: 14 jul. 2020.

${ }^{91}$ LANDAU, David. Political support and structural constitutional law. Alabama Law Review, Tuscaloosa, Alabama, v. 67, p. 1069-1124, 2016. pp. 1085/1086. Disponível em: https://papers.ssrn.com/sol3/papers.cfm?abstract_id=2907084. Acesso em: 14 jul. 2020. 
político e que, quando esse apoio faltar, os tribunais terão poucas chances de sucesso, mesmo com grande esforço ou sofisticação doutrinária. De outro lado, como mostra Landau, os tribunais possuem alguma habilidade para construir apoio para as suas decisões, quando elas faltam no princípio. Podem, por exemplo, tomar decisões para obter apoio de instituições políticas, ou obter apoio de substitutos dessas instituições, no nível internacional ou perante o público em geral. $^{92}$

No caso de o tribunal constitucional receber esses suportes, há diminuição do risco de descumprimento direto ou de represálias contra a decisão judicial, pois os tornam mais visíveis, além de aumentarem o seu custo político frente às demais instituições e ao eleitorado. ${ }^{93}$ Ocorre que, muitas vezes, essa retaliação pode vir de forma sub-reptícia, oculta, o que pode dificultar a atuação judicial.

Assim, a complexidade com que se estruturam as instituições de determinado país oferecem diferentes maneiras de atores políticos se evadirem da decisão judicial para atingir seus objetivos, ainda que não a descumpram diretamente. No entanto, com isso, os esforços judiciais para melhorar as instituições podem, por vezes, causar ainda mais disfunções estruturais.

Além disso, como aponta David Landau, o sistema de governo acaba por ser um preditor significativo do comportamento legislativo na maioria dos contextos políticos modernos. Por exemplo, em sistemas presidencialistas, os parlamentares, individualmente considerados, podem não ter incentivos para efetivamente controlar o Executivo. De outro lado, se as instituições legislativas estiverem nas mãos de partidos fortes que se opõem ao Executivo, será muito provável que o Legislativo exerça mais o seu papel. ${ }^{94}$

Assim, a forma como essa inter-relação entre os Poderes Constituídos ocorre depende dos contextos políticos de cada país, em dado momento. Em alguns países e contextos, a organização das instituições relevantes e os incentivos atuarão para que a separação de poderes

\footnotetext{
92 LANDAU, David. Political support and structural constitutional law. Alabama Law Review, Tuscaloosa, Alabama, v. 67, p. 1069-1124, 2016. Disponível em: https://papers.ssrn.com/sol3/papers.cfm?abstract_id=2907084. Acesso em: 14 jul. 2020.

93 "Existing literature also suggests that the risk of direct noncompliance or reprisal depend in part on whether courts have support from political institutions or the public. Either form of support may make efforts at noncompliance more visible and thus costlier. Similarly, these forms of support may raise the costs of efforts to retaliate against the judiciary" (LANDAU, David. Political support and structural constitutional law. Alabama Law Review, Tuscaloosa, Alabama, v. 67, p. 1075 Disponível em: https: / / papers.ssrn.com/sol3/papers.cfm?abstract_id=2907084. Acesso em: 14 jul. 2020).

94 LANDAU, David. Political support and structural constitutional law. Alabama Law Review, Tuscaloosa, Alabama, v. $\quad 67, \quad$ p. 1069-1124, 2016. Disponível em: https://papers.ssrn.com/sol3/papers.cfm?abstract_id=2907084. Acesso em: 14 jul. 2020.
} 
e o sistema de freios e contrapesos funcione relativamente bem, como nos casos em que o chefe de governo e o parlamento são controlados por diferentes partidos. Contudo, quando o Executivo e o parlamento são controlados pela mesma base partidária, ou onde o sistema partidário é fraco, haverá mais propensão a que o sistema de freios e contrapesos funcione mal. ${ }^{95}$ Como aponta Mark Tushnet, a posição dominante de um partido permite que ele implemente políticas que prejudicam a independência judicial, sem serem bloqueadas pela oposição, nos órgãos políticos, ou pelos próprios juízes. ${ }^{96}$ Neste contexto, será mais difícil uma atuação efetiva da corte constitucional contra elites políticas, pois o poder político estará concentrado e terá mais instrumentos de manobras para descumprir ou se evadir das decisões.

Em perspectiva de direito constitucional comparado, David Landau analisa a atuação dos Tribunais Constitucionais Colombiano e Mexicano. 0 autor aponta que, ao decidir impor limites ao poder do Executivo em relação aos poderes de emergência, o Tribunal Constitucional Colombiano recebeu apoio de atores políticos externos, o que foi fundamental para que houvesse a prevalência dessa decisão; de outro lado, ao abordar o tema da dominância do Executivo e da fraqueza do Legislativo, o Tribunal não recebeu apoio, em razão da natureza do sistema partidário. ${ }^{97}$ Em contraste, as ações da Suprema Corte Mexicana que limitaram poderes regulatórios do Presidente foram levadas a efeito e tiveram como consectário a distribuição do poder, porque o parlamento, liderado pelos outros dois grandes partidos, estava pronto para assumir a tarefa de elaboração de políticas nacionais. ${ }^{98}$

Pesquisas sobre o desempenho de tribunais constitucionais comumente se desenvolvem a partir de dois cenários em abstrato: num deles, os juízes são independentes e podem decidir livremente, sem sofrer sanções; no segundo cenário, os juízes não possuem independência de fato, pois podem sofrer sanções dos governos quando as suas decisões os afrontarem. Segundo essas pressuposições, quando os governos são incapazes de punir os juízes, estes poderiam decidir de acordo com as suas preferências sinceras; no entanto, quando os governos são capazes

95 LANDAU, David. Political support and structural constitutional law. Alabama Law Review, Tuscaloosa, Alabama, v. 67, p. 1069-1124, 2016. pp. 1111/1112. Disponível em: https://papers.ssrn.com/sol3/papers.cfm?abstract_id=2907084. Acesso em: 14 jul. 2020.

${ }_{96}$ TUSHNET, Mark. Preserving Judicial Independence in Dominant Party States. New York Law School Law Review, v. $60, \quad$ n. 1, p. 107-124, 2016. p. 108. Disponível em: https: / /digitalcommons.nyls.edu/cgi/viewcontent.cgi?article=1149\&context=nyls_law_review. Acesso em: 14 jul. 2020.

97 LANDAU, David. Political support and structural constitutional law. Alabama Law Review, Tuscaloosa, Alabama, v. 67, p. 1069-1124, 2016. p. 1113. Disponível em: https://papers.ssrn.com/sol3/papers.cfm?abstract_id=2907084. Acesso em: 14 jul. 2020.

98 LANDAU, David. Political support and structural constitutional law. Alabama Law Review, Tuscaloosa, Alabama, v. $\quad 67, \quad$ p. 1069-1124, 2016. p. 1113. Disponível em: https://papers.ssrn.com/sol3/papers.cfm?abstract_id=2907084. Acesso em: 14 jul. 2020. 
O SUPREMO TRIBUNAL FEDERAL NA CRISE POLÍTICA BRASILEIRA DE 2013-2018: SUAS FORÇAS E FRAQUEZAS DIANTE DAS ELITES POLÍTICAS

FABRÍCIO CASTAGNA LUNARDI

de realizar punições, os juízes seriam estrategicamente deferentes ex ante, de modo que os políticos teriam pouca necessidade de sancioná-los ex post ${ }^{99}$.

Entretanto, na América Latina e, especificamente, no Brasil, essas duas situações hipotéticas quase nunca se concretizam puramente, pois a realidade se apresenta de forma muito mais complexa. A título de exemplo, há diversas situações em que tribunais de países latino-americanos tomaram decisões contra governos e sofreram severas sanções. Nesse tocante, é possível observar que as Cortes Constitucionais da Argentina, Bolívia, Equador, Peru e Venezuela foram alvo de ataques dos governos nas últimas décadas, já em regime democrático. Mesmo em democracias mais estáveis, como Chile, Uruguai e Honduras, os tribunais constitucionais também sofreram diversos ataques em passado recente ${ }^{100}$.

No Brasil, ainda que tradicionalmente os ataques da classe política tenham sido, em termos estatísticos, menos contundentes do em outros países latino-americanos ${ }^{101}$, algo diferente pode ser observado desde a crise política que se instaurou em 2013. Como se pode observar pela análise qualitativa feita no item anterior, desde o início da crise, diversas decisões do STF que desagradaram as maiorias políticas foram alvo de descumprimento, direto ou indireto, e geraram reações sancionatórias por parte da classe política contra a Corte.

Embora não se possa afirmar que o STF, em geral, possua um nível baixo de independência judicial e de poder, outro tipo de análise deve ser feito quando as suas decisões confrontam, ao menos potencialmente, interesses governistas e de elites políticas. Em tais situações, a própria autoridade da Corte Constitucional brasileira pode ser colocada em xeque, com graves consequências para o Estado de Direito e para a democracia.

\footnotetext{
99 HELMKE, Gretchen; STATON, Jeffrey K. The Puzzling Judicial Politics of Latin America: A Theory of Litigation, Judicial Decisions, and Interbranch Conflict. In: HELMKE, Gretchen; RÍOS-FIGUEROA, Julio (Org.). Courts in Latin America. New York: Cambridge University Press, 2011. p. 306-331. p. 308. Disponível em: https://scholarblogs.emory.edu/jeffreystaton/files/2018/03/puzzles.pdf. Acesso em: 14 jul. 2020

100 HELMKE, Gretchen; STATON, Jeffrey K. The Puzzling Judicial Politics of Latin America: A Theory of Litigation, Judicial Decisions, and Interbranch Conflict. In: HELMKE, Gretchen; RÍOS-FIGUEROA, Julio (Org.). Courts in Latin America. New York: Cambridge University Press, 2011. pp. 308/309. Disponível em: https://scholarblogs.emory.edu/jeffreystaton/files/2018/03/puzzles.pdf. Acesso em: 14 jul. 2020

101 Segundo pesquisa empírica realizada por Gretchen Helmke e Jeffrey Staton, as Cortes Constitucionais do Brasil e do Uruguai foram as que menos sofreram ataques por parte dos governos, no período analisado, de 1985 a 2008 (HELMKE, Gretchen; STATON, Jeffrey K. The Puzzling Judicial Politics of Latin America: A Theory of Litigation, Judicial Decisions, and Interbranch Conflict. In: HELMKE, Gretchen; RíOS-FIGUEROA, Julio (Org.). Courts in Latin America. New York: Cambridge University Press, 2011. p. 310. Disponível em: https://scholarblogs.emory.edu/jeffreystaton/files/2018/03/puzzles.pdf. Acesso em: 14 jul. 2020).
} 


\section{CONCLUSÃO}

É possível observar que, desde a “terceira onda” de democratização nos países latinoamericanos, aumentaram os estudos sobre o papel dos tribunais constitucionais na política, as suas dificuldades e seus desafios, de modo que algumas teses mais abstratas, como a relativa à "dificuldade contramajoritária", têm perdido espaço. A despeito disso, no Brasil, teses de "ditadura" do STF e de "supremocracia" ainda formam o grande bloco de críticas à atuação da Corte Constitucional brasileira. Portanto, o estágio atual de estudos sobre o papel dos tribunais constitucionais na América Latina mostra que, no âmbito brasileiro, talvez ainda estejam sendo feitas as perguntas erradas sobre o papel da Corte Constitucional na democracia.

No Brasil, a força e as fraquezas do seu Tribunal Constitucional passaram a ter mais evidência a partir da crise política que iniciou em 2013, quando presidentes, ex-presidentes e mais da metade dos parlamentares federais passaram a ser investigados criminalmente. Diversas questões constitucionais decididas pelo STF em meio a um contexto de crise consideraram mais os envolvidos e as consequências imediatas da decisão do que o paradigma constitucional.

Analisando-se qualitativamente alguns casos julgados pelo STF durante a crise política iniciada em 2013, em que havia interesses governistas ou de elites políticas, é possível observar que ele se viu confrontado com o poder político de diversos atores. Nesse tocante, proferiu decisões diferentes para situações jurídicas idênticas, como na decisão monocrática do Ministro Marco Aurélio Mello que afastou o Senador Renan Calheiros da Presidência do Senado (ADPF n. ${ }^{\circ}$ 402) e, poucos dias depois, diante do descumprimento da decisão, o STF teve de voltar atrás para não evidenciar que a sua autoridade restou afrontada, inclusive revendo entendimento firmado quando do julgamento do caso do Deputado Eduardo Cunha, em que idêntica questão havia sido analisada (Ação Cautelar n. ${ }^{\circ}$ 4070). Além disso, quando o STF impôs medidas cautelares restritivas do mandato parlamentar ao Senador Aécio Neves (Ação Cautelar n. ${ }^{\circ}$ 4327), viu-se confrontado por elites políticas do Senado Federal, que ameaçaram derrubar a decisão judicial, oportunidade em que teve de mudar de entendimento (decidindo contrariamente à posição firmada na Ação Cautelar n. ${ }^{\circ}$ 4070) e "permitir" que o Senado pudesse analisar as medidas cautelares impostas ao Senador (ADI n. ${ }^{\circ}$ 5526), a fim de que não ficasse evidenciado o descumprimento da decisão. Enfim, quando percebeu que suas decisões não seriam cumpridas, o STF voltou atrás, para maquiar esse descumprimento e tentar preservar a sua autoridade institucional. 
Essa investigação teórica e empírica, considerando casos emblemáticos de intervenção do STF na política e nos rumos do país, de um lado, e de outro, a Corte Constitucional brasileira se curvando às elites políticas, aponta que algumas absolutizações como "supremocracia" e “ditadura do Judiciário" não se sustentam em todas as situações, e que teorias jurídicas sobre ativismo e autocontenção judicial sobre são subcomplexas para analisar a questão.

A par disso, reconhecer a vulnerabilidade do Judiciário não implica pretender retirar a sua autoridade. Pelo contrário, como afirma Charles Franklin, “um Judiciário sábio conhece bem sua vulnerabilidade e deve agir para proteger sua autonomia, ao mesmo tempo em que afirma essa independência". ${ }^{102}$

Nesse tocante, é possível observar que abordagens puramente normativas não são capazes de explicar o fenômeno. Análises institucionais e políticas mostram que há diversas formas de descumprimento, direto e indireto, sobreposição e retaliação à Corte Constitucional pela classe política. Nesse tocante, os tribunais constitucionais também utilizam uma série de estratégias, que visam assegurar a sua autoridade, o que influencia as decisões judiciais, na medida em que as Cortes julgam analisando os seus próprios limites e as possibilidades de descumprimento. Além disso, há um conjunto de estratégias de que podem se utilizar para impor as suas decisões (sobretudo, doutrinas antievasão), ou, quando descumpridas, para maquiar esse descumprimento e tentar preservar a sua autoridade.

Além disso, diversas situações analisadas neste artigo apontam que ministros da Corte Constitucional brasileira atuaram estrategicamente, seja quando tomaram decisões que, ao menos potencialmente, afrontariam interesses da classe política, seja para impor as suas decisões, ou, ainda, para impedir que ficassem evidentes os seus limites e a sua falta de força diante de elites políticas concertadas.

Portanto, admitir as fragilidades da Corte Constitucional brasileira, considerar o intrincado jogo político em que está imersa e analisar o conjunto de estratégias dos diversos atores são premissas fundamentais para desenvolver estudos que possam contribuir para melhorar a capacidade institucional da Corte de decidir e impor as suas decisões quando elas afrontam interesses de elites políticas.

102 Tradução livre: FRANKLIN, Charles H.. Behavioral Factors Affecting Judicial Independence. In: BURBANK, Stephen B.; FRIEDMAN, Barry (Eds). Judicial Independence at the Crossroads: An Interdisciplinary Approach. Thousand Oaks: Sage Publications, 2002. p. 148-159. p. 148. Disponível em: http://sk.sagepub.com/books/judicial-independence-at-the-crossroads/n7.xml. Acesso em: 14 jul. 2020. 


\section{REFERÊNCIAS}

AGÊNCIA SENADO. Moraes: STF "substituiu legislador" ao derrubar cláusula de barreira para partidos. Senado Notícias, Brasília, 21 fev. 2017. Disponível em: https://www12.senado.leg.br/noticias/materias/2017/02/21/moraes-stf-substituiulegislador2019-ao-derrubar-clausula-de-barreira-para-partidos. Acesso em: 11 mar. 2019

AGÊNCIA SENADO. Plenário rejeita medidas cautelares contra Aécio Neves e senador retoma mandato. Senado notícias, Brasília, 17 out. 2017. Disponível em:

https: / / www12.senado.leg.br/noticias/materias/2017/10/17/senado-devolve-mandato-a-aecioneves. Acesso em: 13 mar. 2019.

AGÊNCIA SENADO. Senado aprova projeto que altera Lei de Abuso de Autoridade. Senado Notícias, Brasília, 28 abr. 2017. Disponível em:

https://www12.senado.leg.br/noticias/materias/2017/04/26/senado-aprova-projeto-quealtera-lei-de-abuso-de-autoridade. Acesso em: 11 mar. 2019.

ARGUELHES, Diego Werneck; LIMA, João Marcelo da Costa e Silva. Políticas públicas, interpretação judicial e as intenções do legislador: o ProUni e o "cripto-ativismo" do Supremo Tribunal Federal. Revista de Investigações Constitucionais, Curitiba, v. 4, n. 2, p. 163-192, mai.-ago. 2017. p. 164. Disponível em: https://www.scielo.br/pdf/rinc/v4n2/2359-5639-rinc04-02-0163.pdf. Acesso em: 14 jul. 2020.

ARGUELHES, Diego Werneck; RIBEIRO, Leandro Molhano. Preferências, Estratégias e Motivações: Pressupostos institucionais de teorias sobre comportamento judicial e sua transposição para o caso brasileiro. Revista Direito e Práxis, Rio de Janeiro, v. 4, n. 7, p. 85-121, 2013. p. 110. Disponível em: https://www.e-

publicacoes.uerj.br/index.php/revistaceaju/article/view/7503/6366. Acesso em: 14 jul. 2020.

BARROSO, Luís Roberto. Countermajoritarian, Representative, and Enlightened: The roles of constitutional tribunals in contemporary democracies. Revista Direito e Práxis, Rio de Janeiro, v. 9, n. 4, p. 2171-2228, Out-Dez. 2018. Disponível em:

https: //www.scielo.br/pdf/rdp/v9n4/2179-8966-rdp-9-4-2171.pdf. Acesso em: 14 jul. 2020.

BARROSO, Luís Roberto. Curso de direito constitucional contemporâneo: os conceitos fundamentais e a construção do novo modelo. 3. ed. São Paulo: Saraiva, 2011.

BRASIL. Supremo Tribunal Federal. ADI questiona emenda constitucional que permite a prática de vaquejada. Notícias STF, Brasília, 3 jul. 2017. Disponível em:

http://stf.jus.br/portal/cms/verNoticiaDetalhe.asp?idConteudo=348571. Acesso em: 6 jun. 2020.

BRASIL. Supremo Tribunal Federal. Ação Cautelar n. ${ }^{\circ}$ 4070. Suspende o mandato do então Deputado Federal Eduardo Cunha, para afastá-lo da presidência da Câmara dos Deputados e do exercício do mandato parlamentar. Autor: Procurador-Geral da República. Réu: Eduardo Cosentino da Cunha. Relator: Ministro Teori Zavascki. Tribunal Pleno. Julgado em 5 mai. 2016. Acórdão eletrônico. Diário da Justiça Eletrônico: Brasília, DF, n. 225, 21 out. 2016. Disponível 
O SUPREMO TRIBUNAL FEDERAL NA CRISE POLÍTICA BRASILEIRA DE 2013-2018: SUAS FORÇAS E FRAQUEZAS DIANTE DAS ELITES POLÍTICAS

FABRÍCIO CASTAGNA LUNARD

em: http: / / www.stf.jus.br/portal/cms/verNoticiaDetalhe.asp?idConteudo=316009. Acesso em: 14 jul. 2020.

BRASIL. Supremo Tribunal Federal. Ação Cautelar n. ${ }^{\circ}$ 4327. Agravo regimental. Postula a prisão preventiva ou a fixação de medidas cautelares diversas da prisão ao Senador Aécio Neves, e também se questionava se essas medidas deveriam ser deliberadas pela sua Casa Legislativa. Autor: Ministério Público Federal. Réu: Aécio Neves Da Cunha. Relator: Ministro Marco Aurélio, Relator p/ Acórdão: Ministro Roberto Barroso. Primeira Turma. Julgado em 26 set. 2017. Diário da Justiça Eletrônico: Brasília, DF, n. 247, 27 out. 2017. Disponível em: http://www.stf.jus.br/portal/cms/verNoticiaDetalhe.asp?idConteudo=356966. Acesso em: 14 jul. 2020.

BRASIL. Supremo Tribunal Federal. Ação de Descumprimento de Preceito Fundamental $n .^{\circ} 54$. Julgada procedente a ação para declarar a inconstitucionalidade da interpretação segundo a qual a interrupção da gravidez de feto anencéfalo é conduta tipificada nos artigos 124, 126, 128, incisos I e II, todos do Código Penal. Requerente: Confederação Nacional dos Trabalhadores na Saúde - CNTS. Requerido: Presidente da República. Relator: Ministro Marco Aurélio. Tribunal Pleno. Julgado em 12 abr. 2012. Diário da Justiça Eletrônico: Brasília, DF, n. 77, 20 abr. 2012. Disponível em: http://redir.stf.jus.br/paginadorpub/paginador.jsp?docTP=TP\&docID=3707334. Acesso em: 14 jul. 2020.

BRASIL. Supremo Tribunal Federal. Ação de Descumprimento de Preceito Fundamental n. ${ }^{\circ} 132$. Perda parcial de objeto. Recebimento, na parte remanescente, como ação direta de inconstitucionalidade. Interpretação do art. 1.723 do Código Civil em conformidade com a Constituição Federal (técnica da "interpretação conforme"). Reconhecimento da união homoafetiva como família. Procedência das ações. Requerente: Governador do Estado do Rio De Janeiro. Requeridos: Tribunais de Justiça dos Estados. Relator: Ministro Ayres Britto. Tribunal Pleno. Julgado em 5 mai. 2011. Diário da Justiça Eletrônico: Brasília, DF, n. 198, 14 out. 2011. Disponível em: https://redir.stf.jus.br/paginadorpub/paginador.jsp?docTP=AC\&docID=628633. Acesso em: 14 jul. 2020.

BRASIL. Supremo Tribunal Federal. Ação de Descumprimento Fundamental n. ${ }^{\circ} 186$. Questiona atos que instituíram sistema de reserva de vagas com base em critério étnico-racial (cotas) no processo de seleção para ingresso em instituição pública de ensino superior. Julgados improcedentes os pedidos. Requerente: DEMOCRATAS - DEM. Requerido: Conselho de Ensino, Pesquisa e Extensão da Universidade de Brasília - CEPE; Reitor da Universidade de Brasília. Relator: Ministro Ricardo Lewandowski. Julgado em 26 abr. 2012. Diário da Justiça Eletrônico: Brasília, DF, n. 86, 4 mai. 2012. Disponível em:

http: //www.stf.jus.br/portal/cms/verNoticiaDetalhe.asp?idConteudo=278000. Acesso em 14 jul. 2020.

BRASIL. Supremo Tribunal Federal. Ação de Descumprimento Fundamental n. ${ }^{\circ} 402$. Pretende o afastamento cautelar do exercício da Presidência do Senado Federal, por ser réu em processo penal. Autor: Rede Sustentabilidade. Réu: Presidente da Câmara dos Deputados. Relator: Ministro Marco Aurélio. Acompanhamento processual. Disponível em: http: / / www.stf.jus.br/portal/processo/verProcessoAndamento. asp?incidente $=4975492$. Acesso em: 10 mar. 2019.

BRASIL. Supremo Tribunal Federal. Ação Direta de Inconstitucionalidade n. ${ }^{\circ} 1351$. Julgada procedente a ação para declarar inconstitucionalidade de dispositivos de lei que, em face da 
O SUPREMO TRIBUNAL FEDERAL NA CRISE POLÍTICA BRASILEIRA DE 2013-2018: SUAS FORÇAS E FRAQUEZAS DIANTE DAS ELITES POLÍTICAS

gradação de votos obtidos por partido político, afasta o funcionamento parlamentar e reduz, substancialmente, o tempo de propaganda partidária gratuita e a participação no rateio do Fundo Partidário. Requerente: Partido Comunista do Brasil - PC do B e outros. Relator: Ministro Marco Aurélio. Tribunal Pleno. Julgado em 7 dez. 2006. Diário da Justiça de 30 mar. 2007. Revista Trimestral de Jurisprudência, Brasília, v. 207-01, p. 116. Disponível em: http: / / redir.stf.jus.br/paginadorpub/paginador.jsp?docTP=AC\&docID=416150. Acesso em: 14 jul. 2020.

BRASIL. Supremo Tribunal Federal. Ação Direta de Inconstitucionalidade $n .^{\circ} 3510$. Pede a declaração de inconstitucionalidade de dispositivos a Lei de Biossegurança (Lei n. ${ }^{\circ} 11.105 / 2005$ ). Julgados improcedentes os pedidos. Requerente: Procurador-Geral da República. Requeridos: Presidente da República; Congresso Nacional. Relator: Ministro Ayres Britto. Tribunal Pleno. Julgado em 29 mai. 2008. DJe-096, 28 mai. 2010. Revista Trimestral de Jurisprudência, Brasília, v. 214.Disponível em: http://www.stf.jus.br/arquivo/cms/publicacaoRTJ/anexo/214_1.pdf. Acesso em 14 jul. 2020.

BRASIL. Supremo Tribunal Federal. Ação Direta de Inconstitucionalidade n. ${ }^{\circ} 4277$. Interpretação do art. 1.723 do Código Civil em conformidade com a Constituição Federal (técnica da "interpretação conforme"). Reconhecimento da união homoafetiva como família. Julgada procedente a ação. Requerente: Procuradora-Geral da República. Requerido: Presidente da República; Congresso Nacional. Relator: Ministro Ayres Britto. Tribunal Pleno. Julgado em 5 mai. 2011. Diário da Justiça Eletrônico: Brasília, DF, n. 198, 14 out. 2011. Disponível em: http: / /redir.stf.jus.br/paginadorpub/paginador.jsp?docTP=AC\&docID=628635. Acesso em 14 jul. 2020.

BRASIL. Supremo Tribunal Federal. Ação Direta de Inconstitucionalidade n. ${ }^{\circ} 4650$. Julgado parcialmente procedente o pedido. Declarou a inconstitucionalidade dos dispositivos legais que autorizavam as contribuições de pessoas jurídicas às campanhas eleitorais. Com relação às pessoas físicas, as contribuições ficam reguladas pela lei em vigor. Autor: Conselho Federal da Ordem dos Advogados do Brasil. Requeridos: Congresso Nacional; Presidente da República. Relator: Ministro Luiz Fux. Tribunal Pleno. Julgado em 17 set. 2015. Diário da Justiça Eletrônico: Brasília, DF, n. 34, 24 fev. 2016. Disponível em:

http: //www.stf.jus.br/portal/cms/verNoticiaDetalhe.asp?idConteudo=300015. Acesso em: 14 jul. 2020.

BRASIL. Supremo Tribunal Federal. Ação Direta de Inconstitucionalidade $n^{\circ} 4983$. Foi declarada a inconstitucionalidade da Lei Estadual questionada, para vedar a denominada vaquejada.

Requerente: Procurador-Geral da República. Requeridos: Governador do Estado do Ceará; Assembleia Legislativa do Estado do Ceará. Relator: Ministro Marco Aurélio. Tribunal Pleno. Julgado em 6 out. 2016. Diário da Justiça Eletrônico: Brasília, DF, n. 87, 27 abr. 2017. Disponível em: http: //redir.stf.jus.br/paginadorpub/paginador.jsp?docTP=TP\&docID=12798874. Acesso em: 14 jul. 2020.

BRASIL. Supremo Tribunal Federal. Ação Direta de Inconstitucionalidade $n .^{\circ} 5526$. Julgado parcialmente procedente o pedido. O Poder Judiciário dispõe de competência para impor, por autoridade própria, as medidas cautelares a que se refere o art. 319 do Código de Processo Penal, mas deve se encaminhar à Casa Legislativa a que pertencer o parlamentar, para os fins a que se refere o art. $53, \S 2^{\circ}$, da Constituição, a decisão pela qual se aplique medida cautelar, sempre que a execução desta impossibilitar, direta ou indiretamente, o exercício regular de mandato parlamentar. Requerentes: Partido Progressista - PP; Partido Social Cristão - PSC. 
Relator p/ acórdão: Ministro Alexandre de Moraes. Julgado em 11 out. 2017. Diário da Justiça Eletrônico: Brasília, DF, n. 159, 7 ago. 2018. Disponível em:

http://www.stf.jus.br/portal/cms/verNoticiaDetalhe.asp?idConteudo=362170. Acesso em: 14 jul. 2020.

BRASIL. Supremo Tribunal Federal. Ação Direta de Inconstitucionalidade $n^{\circ} 5728$. Postula a declaração de inconstitucionalidade da Emenda Constitucional n. ${ }^{\circ} 96$, que permite "as práticas desportivas que utilizem animais, desde que sejam manifestações culturais". Requerente: Fórum Nacional de Proteção e Defesa Animal. Requerido: Mesa da Câmara dos Deputados.

Acompanhamento Processual. Disponível em:

http: //stf.jus.br/portal/processo/verProcessoAndamento.asp?numero=5728\&classe=ADI\&origem $=$ AP\&recurso=0\&tipoJulgamento=M. Acesso em: 6 jun. 2020.

BRASIL. Supremo Tribunal Federal. Ação Direta de Inconstitucionalidade $n^{\circ} 5772$. Postula a declaração de inconstitucionalidade da Emenda Constitucional $n .^{\circ} 96$, que permite as práticas desportivas que utilizem animais, desde que sejam manifestações culturais. Requerente: Procurador-Geral da República. Requeridos: Presidente da República; Congresso Nacional. Acompanhamento Processual. Disponível em:

http: //portal.stf.jus.br/processos/detalhe.asp?incidente=5259991. Acesso em: 6 jun. 2020.

BRASIL. Supremo Tribunal Federal. Estatísticas do STF: ADI. Disponível em:

http://www.stf.jus.br/portal/cms/verTexto.asp?servico=estatistica\&pagina=adi. Acesso em: 15 nov. 2018.

BRASIL. Supremo Tribunal Federal. Estatísticas do STF: ADC. Disponível em: http: //www.stf.jus.br/portal/cms/verTexto.asp?servico=estatistica\&pagina=adc. Acesso em: 15 nov. 2018.

BRASIL. Supremo Tribunal Federal. Mandado de Segurança $n .^{\circ} 34070$. Suspende a nomeação de Luiz Inácio Lula da Silva para o cargo de Ministro da Casa Civil, pela então Presidenta Dilma Rousseff. Impetrante: Partido Popular Socialista. Impetrado: Presidente da República. Medida Cautelar. Liminar. Relator: Min. Gilmar Mendes. Julgado em 18 mar. 2016. Diário da Justiça Eletrônico: Brasília, DF, n. 54, 28 mar. 2016. Disponível em:

http://www.stf.jus.br/arquivo/cms/noticiaNoticiaStf/anexo/ms34070.pdf. Acesso em: 14 jul. 2020.

CÂMARA DOS DEPUTADOS. Gilmar Mendes diz que STF errou em decisão sobre cláusula de barreira. Câmara Notícias, Brasília, 21 mar. 2017. Disponível em:

http: //www2.camara.leg.br/camaranoticias/noticias/POLITICA/526598-GILMAR-MENDES-DIZQUE-STF-ERROU-EM-DECISAO-SOBRE-CLAUSULA-DE-BARREIRA.html. Acesso em: 11 mar. 2019.

CASADO, Letícia; FERNANDES, Talita. Cármen Lúcia se reúne com presidente do Senado para tratar caso Aécio. Folha de São Paulo, São Paulo, 2/10/2017. Disponível em:

https: / /www1.folha.uol.com.br/poder/2017/10/1923541-carmen-lucia-se-reune-compresidente-do-senado-para-tratar-caso-aecio.shtml. Acesso em: 13 mar. 2019.

DELMANTO, Roberto. A ditadura do Judiciário. Migalhas, 15 mar. 2018. Disponível em: http: / / www.migalhas.com.br/dePeso/16,MI276327,101048-A+ditadura+do+Judiciario. Acesso em: 10 mar. 2019. 
DENNING, Brannon P.; KENT, Michael B. Jr. Anti-Anti-Evasion in Constitutional Law. Florida State University Law Review, v. 41, n. 2, p. 397-434, Winter 2014. p. 420. Disponível em: https://ir.law.fsu.edu/lr/vol41/iss2/3/. Acesso em: 14 jul. 2020.

ENTENDA o novo fundo público para campanhas eleitorais aprovado na Câmara. BBC BRASIL, 4/10/2017. Disponível em: http://www.bbc.com/portuguese/brasil-41507850. Acesso em: 13 mar. 2019.

FRANKLIN, Charles H.. Behavioral Factors Affecting Judicial Independence. In: BURBANK, Stephen B.; FRIEDMAN, Barry (Eds). Judicial Independence at the Crossroads: An Interdisciplinary Approach. Thousand Oaks: Sage Publications, 2002. p. 148-159. p. 148. Disponível em: http://sk.sagepub.com/books/judicial-independence-at-the-crossroads/n7.xml. Acesso em: 14 jul. 2020.

GARCIA, Gustavo; RAMALHO, Renan. Senado decide descumprir liminar para afastar Renan e aguardar plenário do STF. G1, Brasília, 6 dez. 2016. Disponível em: https://g1.globo.com/politica/noticia/renan-senado-decide-nao-cumprir-liminar-e-aguardardecisao-do-plenario-do-stf.ghtml. Acesso em: 13 mar. 2019.

GOVERNO reserva quase R\$ 900 milhões para fundo partidário. G1, São Paulo, 4 set. 2017. Disponível em: http://g1.globo.com/jornal-nacional/noticia/2017/09/governo-reserva-quase-r900-milhoes-para-fundo-partidario.html. Acesso em: 13 mar. 2019.

HELMKE, Gretchen. Public Support and Judicial Crises in Latin America. Journal of Constitutional Law, v. 13, n. 2, p. 397-411, 2010. pp. 402/403. Disponível em: https: / / scholarship.law.upenn.edu/cgi/viewcontent.cgi?article=1079\&context=jcl. Acesso em: 14 jul. 2020

HELMKE, Gretchen; STATON, Jeffrey K. The Puzzling Judicial Politics of Latin America: A Theory of Litigation, Judicial Decisions, and Interbranch Conflict. In: HELMKE, Gretchen; RÍOS-

FIGUEROA, Julio (Org.). Courts in Latin America. New York: Cambridge University Press, 2011. p. 306-331. p. 327. Disponível em:

https://scholarblogs.emory.edu/jeffreystaton/files/2018/03/puzzles.pdf. Acesso em: 14 jul. 2020

KÖHLER, Marco Vicente Dotto. Legitimidade democrática da jurisdição constitucional, dificuldade contramajoritária do Poder Judiciário e conflito intergeracional. Revista do CEJUR/TJSC: Prestação Jurisdicional, Florianópolis, v. 5, n. 01, p. 215-227, dez. 2017. Disponível em: https://revistadocejur.tjsc.jus.br/cejur/article/view/226/133. Acesso em: 14 jul. 2020.

LANDAU, David. Political support and structural constitutional law. Alabama Law Review, Tuscaloosa, Alabama, v. 67, p. 1069-1124, 2016. p. 1074. Disponível em: https://papers.ssrn.com/sol3/papers.cfm?abstract_id=2907084. Acesso em: 14 jul. 2020.

MARMELSTEIN, George. Efeito Backlash da Jurisdição Constitucional: reações políticas ao ativismo judicial. Bolonha: 2016. Texto-base de palestra proferida durante o Terceiro Seminário Ítalo-Brasileiro. Disponível em:

https://www.academia.edu/35675035/Efeito_Backlash_da_Jurisdi\%C3\%A7\%C3\%A3o_Constitucinal . Acesso em: 3 jun. 2020. p. 3. 
O SUPREMO TRIBUNAL FEDERAL NA CRISE POLÍTICA BRASILEIRA DE 2013-2018: SUAS FORÇAS E FRAQUEZAS DIANTE DAS ELITES

MELLO, Patrícia Perrone Campos. Quando julgar se torna um espetáculo: a interação entre o Supremo Tribunal Federal e a opinião pública, a partir de reflexões da literatura estrangeira. Revista de Direito Internacional, Brasília, v. 14, n. 1, p. 402-423, 2017. p. 420. Disponível em: https://www.publicacoesacademicas.uniceub.br/rdi/article/view/4427/pdf. Acesso em: 14 jul. 2020.

MILLIGAN, Luke M. Congressional End-Run: The Ignored Constraint on Judicial Review. Georgia Law Review, v. 45, n. 1, p. 211-274, Fall 2010. pp. 252-254. Disponível em: https://papers.ssrn.com/sol3/papers.cfm?abstract_id=1709405. Acesso em: 14 jul. 2020.

MOURA, Rafael Moraes; BONFIM, Isabela. TJs veem retaliação em comissão de supersalários. Estadão, Brasília, 16 nov. 2016. Disponível em: http://politica.estadao.com.br/noticias/geral,tjs-veem-retaliacao-em-comissao-desupersalarios, 10000088443. Acesso em: $1^{\circ}$ mar. 2019

MORO divulga grampo de Lula e Dilma; Planalto fala em Constituição violada. G1, São Paulo, 16 mar. 2016. Disponível em: http://g1.globo.com/politica/noticia/2016/03/moro-divulga-grampode-lula-e-dilma-planalto-fala-em-constituicao-violada.html. Acesso em: 13 mar. 2019.

PARTLETT, William. Courts and Constitution-Making. Wake Forest Law Review, Wake Forest University School of Law, Winston-Salem, CN, v. 50, p. 921-949, 2015. p. 948. Disponível em: https://papers.ssrn.com/sol3/papers.cfm?abstract_id=2730359. Acesso em: 14 jul. 2020.

PONTES, Felipe. Cármen Lúcia diz que dará urgência à análise da liminar que afastou Renan. EBC Agência Brasil, Brasília, 6 dez. 2016. Disponível em:

http://agenciabrasil.ebc.com.br/politica/noticia/2016-12/carmen-lucia-diz-que-dara-urgenciaanalise-da-liminar-que-afastou-renan. Acesso em: 13 mar. 2019.

RAMALHO, Renan. Cármen Lúcia ouve ministros e marca para esta quarta decisão sobre Renan. G1, São Paulo, 6 dez. 2016. Disponível em: https://g1.globo.com/politica/noticia/carmen-luciaouve-ministros-e-marca-para-esta-quarta-decisao-sobre-renan.ghtml. Acesso em: 13 mar. 2019.

SARDINHA, Edson. De olho no Judiciário, Renan instala comissão para frear supersalários. Congresso em foco, Brasília, 10 nov. 2016. Disponível em:

http: //congressoemfoco.uol.com.br/noticias/de-olho-no-judiciario-renan-instala-comissao-parafrear-supersalarios/. Acesso em: $1^{\circ}$ mar. 2019.

SENADO FEDERAL. Consulta Pública: Projeto de Lei do Senado $\mathrm{n}^{\circ} 280$, de 2016. Disponível em: https://www25.senado.leg.br/web/atividade/materias/-/materia/126377. Acesso em: 11 mar. 2019.

SENADO FEDERAL. Parecer da Comissão de Constituição, Justiça e Cidadania, sobre os Projetos de Lei do Senado $n^{\circ} 280$, de 2016, do Senador Renan Calheiros, e $n^{\circ} 85$, de 2017 , do Senador Randolfe Rodrigues, que definem os crimes de abuso de autoridade e dão outras providências. Disponível em: http://legis.senado.leg.br/sdleg-

getter/documento?dm=5239240\&disposition=inline. Acesso em: 13 mar. 2019.

SOUZA NETO, Cláudio Pereira de; SARMENTO, Daniel. Notas sobre jurisdição constitucional e democracia: a questão da "última palavra" e alguns parâmetros de autocontenção judicial. 
Revista Quaestio luris, Rio de Janeiro, v. 6, n. 2, p. 119-161, 2013. Disponível em: https://www.e-publicacoes.uerj.br/index.php/quaestioiuris/article/view/11773/9225. Acesso em: 14 jul. 2020.

TOFFOLI defende criação de cláusula de barreira e fim de coligações partidárias. Consultor Jurídico, 20/4/2017. Disponível em: https://www.conjur.com.br/2017-abr-20/toffoli-defendecriacao-clausula-barreira-fim-coligacoes. Acesso em: 11 mar. 2019.

TUSHNET, Mark. Preserving Judicial Independence in Dominant Party States. New York Law School Law Review, v. 60, n. 1, p. 107-124, 2016. p. 109. Disponível em: https: / / digitalcommons.nyls.edu/cgi/viewcontent.cgi?article=1149\&context=nyls_law_review. Acesso em: 14 jul. 2020.

VAROL, Ozan O. Structural Rights. Georgetown Law Journal, v. 105, n. 4, p. 1001-1054, abr. 2017 Disponível em: https://papers.ssrn.com/sol3/papers.cfm?abstract_id=2746175. Acesso em: 14 jul. 2020.

VILHENA, Oscar. Supremocracia. Revista de Direito do Estado, Rio de Janeiro, a. 3, n. 12, p. 5575, out.-dez. 2008. Disponível em: https://www.scielo.br/pdf/rdgv/v4n2/a05v4n2.pdf. Acesso em: 14 jul. 2020.

PERISSINOTTO, Renato. As elites políticas: questões de teoria e método. Curitiba: IBPEX, 2009. pp. 83/84/97.

Recebido em: 13.03.2019 / Revisões requeridas em: 01.05.2020 / Aprovado em: 05.06.2020 / Publicado em: 24.07.2020

\section{COMO FAZER REFERÊNCIA AO ARTIGO (ABNT):}

LUNARDI, Fabrício Castagna. O Supremo Tribunal Federal na crise política brasileira de 2013-2018: suas forças e fraquezas diante das elites políticas. Revista Eletrônica do Curso de Direito da UFSM, Santa Maria, RS, v. 15, n. 2, e37281, maio/ago. 2020. ISSN 1981-3694. DOI: http://dx.doi.org/10.5902/1981369437281. Disponível em: https://periodicos.ufsm.br/revistadireito/article/view/37281. Acesso em: dia mês. ano.

Direitos autorais 2020 Revista Eletrônica do Curso de Direito da UFSM

Editores responsáveis: Rafael Santos de Oliveira e Angela Araujo da Silveira Espindola

\section{(c)}

Esta obra está licenciada com uma Licença Creative Commons Atribuição-NãoComercial-SemDerivações 4.0 Internacional.

\section{SOBRE O AUTOR}

\section{FABRÍCIO CASTAGNA LUNARDI}

Doutor e Mestre em Direito pela Universidade de Brasília (UnB). Possui Graduação em Direito e Especialização em Direito Civil pela Universidade Federal de Santa Maria (UFSM). Juiz de Direito da Justiça do Distrito Federal e dos Territórios desde 2009. Foi juiz auxiliar da Presidência do STJ em 2019, coordenando Força-Tarefa. Exerceu o cargo de Advogado da União (AGU) no período de 2006 a 2009. Defensor Público do Estado do Rio Grande do Sul no ano de 2006. Foi Advogado privado em 2005 e 2006. Professor de direito processual civil e de direito constitucional da UFSM no período de 2006 a 2007. Aprovado nos 
ISSN 1981-3694

(DOI): $10.5902 / 1981369437281$

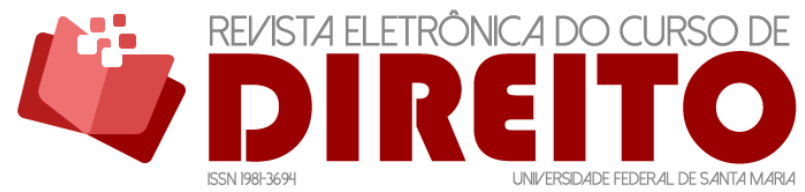

O SUPREMO TRIBUNAL FEDERAL NA CRISE POLÍTICA BRASILEIRA DE 2013-2018: SUAS FORÇAS E FRAQUEZAS DIANTE DAS ELITES

concursos públicos para os cargos de Defensor Público (RS), Procurador do Estado (RS), Advogado da União, Procurador Federal, Procurador da Fazenda Nacional, Promotor de Justiça do MP/PR (1 $1^{\circ}$ lugar) e Juiz de Direito Substituto do TJDFT. É professor da Escola Nacional de Formação e Aperfeiçoamento de Magistrados (ENFAM), da Escola de Formação Judiciária do TJDFT e dos cursos de Pós-Graduação Lato Sensu do Instituto Brasiliense de Direito Público (IDP). Professor Visitante no Mestrado Interinstitucional Acadêmico em Direito Constitucional do IDP. Membro do Grupo de Trabalho Decisões Criminais (na ENFAM) e do Grupo de Trabalho para Otimização de Julgamentos do Tribunal do Júri (no CNJ). Coordenador-Geral da Escola de Formação Judiciária do TJDFT. Coordenador da Linha de Pesquisa Direito Processual, Sistemas de Justiça e Inovação, da EFJ/TJDFT. Coordenador da Sublinha de Pesquisa Direito Processual Civil, Inovação, Justiça e Sociedade e da Sublinha Gestão de Processos (EFJ/TJDFT). Coordenador de diversos projetos de pesquisa na área de gestão e inovação no Poder Judiciário. A unidade judicial de que é titular (Tribunal do Júri de Samambaia) ocupa o $1^{\circ}$ lugar no ranking nacional de melhor desempenho entre Tribunais do Júri do país (CNJ, relatório de 2020, referente ao ano de 2019). Autor dos livros Curso de Direito Processual Civil (Saraiva, 2019), O STF na política e a política no STF (Saraiva, 2020), dentre outros; coautor dos livros Curso de Sentença Cível (Juspodivm, 2019) e Curso de Sentença Penal (Juspodivm, 2020). Tem autoria de dezesseis livros e mais de três dezenas de artigos publicados. Examinador em diversas Bancas de Concursos Públicos na área do Direito organizados pelo CESPE/CEBRASPE. 